\title{
Metabolic-Associated Fatty Liver Disease (MAFLD), Diabetes, and Cardiovascular Disease: Associations with Fructose Metabolism and Gut Microbiota
}

\author{
Karolina Drożdż ${ }^{1}$, Katarzyna Nabrdalik ${ }^{1,2, * \mathbb{D}}$, Weronika Hajzler ${ }^{3} \mathbb{D}$, Hanna Kwiendacz ${ }^{1}$, Janusz Gumprecht ${ }^{1}$ \\ and Gregory Y. H. Lip ${ }^{1,2,4}$ (D)
}

Citation: Drożdż, K.; Nabrdalik, K.; Hajzler, W.; Kwiendacz, H.;

Gumprecht, J.; Lip, G.Y.H.

Metabolic-Associated Fatty Liver Disease (MAFLD), Diabetes, and Cardiovascular Disease: Associations with Fructose Metabolism and Gut Microbiota. Nutrients 2022, 14, 103. https://doi.org/10.3390/nu14010103

Academic Editor: Fátima Pérez De Heredia

Received: 25 November 2021 Accepted: 23 December 2021 Published: 27 December 2021

Publisher's Note: MDPI stays neutral with regard to jurisdictional claims in published maps and institutional affiliations.

Copyright: (C) 2021 by the authors. Licensee MDPI, Basel, Switzerland. This article is an open access article distributed under the terms and conditions of the Creative Commons Attribution (CC BY) license (https:// creativecommons.org/licenses/by/ $4.0 /)$.
1 Department of Internal Medicine, Diabetology and Nephrology in Zabrze, Faculty of Medical Sciences in Zabrze, Medical University of Silesia, 40-055 Katowice, Poland; karolina.drozdz92@gmail.com (K.D.); hkwiendacz@sum.edu.pl (H.K.); jgumprecht@sum.edu.pl (J.G.); gregory.lip@liverpool.ac.uk (G.Y.H.L.)

2 Liverpool Centre for Cardiovascular Science, University of Liverpool and Liverpool Heart \& Chest Hospital, Liverpool L14 3PE, UK

3 Doctoral School, Department of Pediatric Hematology and Oncology in Zabrze, Faculty of Medical Sciences in Zabrze, Medical University of Silesia, 40-055 Katowice, Poland; hajzlerweronika@gmail.com

4 Department of Clinical Medicine, Aalborg University, 9100 Aalborg, Denmark

* Correspondence: knabrdalik@sum.edu.pl

\begin{abstract}
Non-alcoholic fatty liver disease (NAFLD) is an increasingly common condition associated with type 2 diabetes (T2DM) and cardiovascular disease (CVD). Since systemic metabolic dysfunction underlies NAFLD, the current nomenclature has been revised, and the term metabolic-associated fatty liver disease (MAFLD) has been proposed. The new definition emphasizes the bidirectional relationships and increases awareness in looking for fatty liver disease among patients with T2DM and CVD or its risk factors, as well as looking for these diseases among patients with NAFLD. The most recommended treatment method of NAFLD is lifestyle changes, including dietary fructose limitation, although other treatment methods of NAFLD have recently emerged and are being studied. Given the focus on the liver-gut axis targeting, bacteria may also be a future aim of NAFLD treatment given the microbiome signatures discriminating healthy individuals from those with NAFLD. In this review article, we will provide an overview of the associations of fructose consumption, gut microbiota, diabetes, and CVD in patients with NAFLD.
\end{abstract}

Keywords: metabolic-associated fatty liver disease; diabetes mellitus; cardiovascular disease; fructose; microbiota

\section{Introduction}

In 1986, the term nonalcoholic fatty liver disease (NAFLD) was proposed by Schaner and Thaler [1]. Almost 10 years later, Leonardo et al. hypothesized that NAFLD could be associated with cardiovascular disease (CVD) [2], and soon after, the first NAFLD guidelines emerged [3-5]. The most relevant events in the NAFLD history [1-8] are presented in Figure 1.

The definition of NAFLD combines the presence of steatosis in more than $5 \%$ of hepatocytes and metabolic risk factors, especially obesity and T2DM, and exclusion of excessive alcohol consumption defined as $\geq 30 \mathrm{~g}$ per day for men and $\geq 20 \mathrm{~g}$ per day for women, or other chronic liver diseases [9]. It should be noted that the liver is a primary organ for lipid and glucose homeostasis and is the focus of cardiometabolic disease. In 2020, fatty liver was redefined from negative (absence of excessive alcohol consumption and other known causes of liver disease) to a more positively stated metabolic associated fatty liver disease (MAFLD) [10]. 
- First NAFLD guidelines of Asia-Pacific Association for Liver Research Association (APASL)

-Statement of the European Liver Research Association (EASL) 2009 deliberation on NAFLD / NASH

Figure 1. Fatty liver disease timeline [1-8].

The latter definition of MAFLD is based on the presence of hepatic steatosis and at least one other condition such as overweight/obesity, T2DM, or metabolic abnormalities with no additional exclusion criteria $[10,11]$. Metabolic abnormalities included in the definition cover at least two features from the following: increased waist circumference, arterial hypertension, hypertriglyceridemia, low high-density cholesterol (HDL-C), prediabetes, insulin resistance, and subclinical inflammation [10] (Figure 2). This new definition underlines the importance of cardiometabolic risk factors contributing to liver disease even among patients with other liver diseases and who drink alcohol [10]. Although it should be noticed that although the new definition has been proposed by a panel of international experts from 22 countries, this new nomenclature is not yet accepted by the American Association for the Study of Liver Disease and the European Association for the Study of Liver Disease.

Diabetes mellitus is a heterogeneous group of disorders that results in an increase in blood glucose concentration, yet the pathophysiological processes underlying type 1 and type 2 of the disease differ. Insulin resistance, which is tightly linked to T2DM, is not always present in type 1 of the disease, thereby explaining the different prevalence of NAFLD in those two subpopulations of patients [11]. 


\section{Hepatic steatosis in adults}

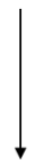

Overweight/obesity

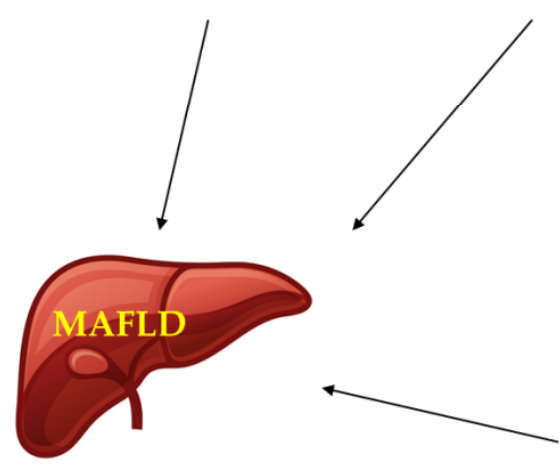

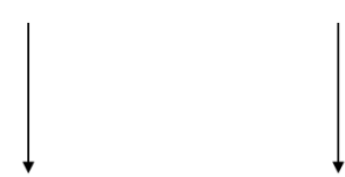

Type 2 diabetes

Lean/ normal weight

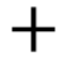

Presence of at least two of the following metabolic risk abnormalities:

\footnotetext{
1. Waist circumference $\geq 102 \mathrm{~cm}$ in Caucasian men

and $\geq 88 \mathrm{~cm}$ in women (or $\geq 90$ in Asian men and $\geq 80$ in Asian women)

2. Blood pressure $\geq 130 / 85 \mathrm{mmHg}$ or hypertension drug treatment

3. Plasma triglicerydes $\geq 150 \mathrm{mg} / \mathrm{dL}$ ( $\geq 1.70 \mathrm{~mol} / \mathrm{L}$ ) or its drug treatment

4. Plasma HDL-cholesterol $<40 \mathrm{mg} / \mathrm{dL}(<1.0 \mathrm{mmol} / \mathrm{L})$ for men

and $<50 \mathrm{mg} / \mathrm{dL}(<1.3 \mathrm{mmol} / \mathrm{L})$ for women or its drug treatment

5. Prediabetes

6. Homeostasis model assessment of insulin resistance (HOMA-IR)

score $\geq 2.5$

7. Plasma high - sensitivity C-reactive protein level $>2 \mathrm{mg} / \mathrm{L}$
}

Figure 2. Diagnostic criteria for MAFLD (metabolic dysfunction-associated fatty liver disease) [12].

NAFLD has a high prevalence in the general population, varying from $13.5 \%$ in Africa to $31.8 \%$ in the Middle East [13]. It is diagnosed in $47.3-63.7 \%$ of patients with T2DM and up to $80 \%$ of people with obesity $[14,15]$. Liver failure related to NAFLD is the second leading cause of liver transplantation in the western world [15]. The high prevalence of NAFLD is driven mainly by an unhealthy lifestyle, including dietary factors such as high levels of saturated fats, cholesterol, or fructose [16].

Consumption of fructose has increased over the last century mainly due to the use of high-fructose corn syrup [17]. This phenomenon has been studied in the context of liver disease, obesity, and diabetes, where it promotes hepatic de novo lipogenesis, leading to lipid accumulation in the liver and insulin resistance [18-20]. A new perspective on NAFLD emerged during the last decade when scientists additionally focused on the relationship of microbiota with metabolic disease and its relation to NAFLD, where microbiome signatures discriminate healthy individuals from those with NAFLD [21].

While there is the perception that NAFLD is a benign liver condition, it is the second most common cause of end-stage liver disease [22] and the second cause of primary liver cancer in patients waiting for liver transplants in the US [13] and Europe [23]. Even more importantly, the leading cause of death among patients with NAFLD is not associated with the liver itself but with CVD [24].

Since MAFLD is a new term and has been seldom used in published studies, for this review article, we have summarized the current state of knowledge regarding NAFLD and its association with fructose consumption, microbiota, diabetes, and CVD.

\section{NAFLD and Fructose}

Fructose's use in foods was limited until the late 1960s due to its high price [25]. Since then, it has become freely available and has been shown to exert a positive effect in the treatment of diabetes since fructose does not require insulin to be metabolized and has no effect on fasting blood glucose levels and urinary glucose excretion [26,27]. Nowadays, the way scientists look at fructose has changed, and it is now known as a risk factor in the development of obesity and several metabolic disturbances, NAFLD, among others [19].

Fructose is a major dietary monosaccharide that occurs naturally in ripe fruits, honey, and in small amounts in some vegetables such as carrot, onion, paprika, and sweet potato. 
It also comes in industrially manufactured foods because it is a main ingredient in the most widely used sweeteners like disaccharide sucrose (table sugar, composed of one glucose molecule and one fructose) and high fructose glucose syrup (mixture of fructose with sucrose or glucose) [18,27].

Fructose, in contrast to glucose, is almost totally cleared from circulation by the liver with the use of glucose transporter type-5 (GLUT 5). A large amount of acetyl-CoA is produced following fructose uptake because fructose clearance omits glycolysis, which is the rate-limiting step in acetyl-CoA production [28]. Some acetyl-CoA is used for ATP production, but the excess amount is used for de novo lipogenesis, which is one of the mechanisms proposed for how consuming fructose leads to NAFLD [28,29]. Based on the results of studies on animals and humans with fructose overfeeding, high fructose consumption ( $25 \%$ of energy requirement) may increase visceral adiposity, postprandial hypertriglyceridemia, and insulin resistance by acting on de novo lipogenesis [30].

However, it is not only lipogenesis; other hepatotoxic effects are exerted by fructose, namely inducing an increase in oxidative stress [31]. Fructose is able to directly generate reactive oxygen species (ROS) and lead to hepatocellular damage through protein fructosylation [32]. Because of the increased consumption of processed foods, fructose consumption has increased dramatically, by $30 \%$ over the last 40 years and by $500 \%$ over the last century [33]. Also, there was more than a 40\% increase in the intake of sugar-sweetened beverages (SSB) from 1990 to 2016 [34]. Because free sugars consumption has a proven association with metabolic diseases and cancer, it has since been recommended by the World Health Organization (WHO) to decrease its consumption to less than $10 \%$ of total daily energy intake [35].

Numerous animal and human studies have revealed the association of a close relationship between the consumption of fructose and the development of NAFLD (Table 1).

Table 1. The association between NAFLD and fructose consumption.

\begin{tabular}{|c|c|c|c|c|c|}
\hline $\begin{array}{l}\text { Authors } \\
\text { (Year) }\end{array}$ & Study Type & $\begin{array}{l}\text { Studies/ } \\
\text { Participants } \\
\text { (N) }\end{array}$ & $\begin{array}{l}\text { Average } \\
\text { Duration of } \\
\text { Follow-Up }\end{array}$ & Population & Findings \\
\hline $\begin{array}{l}\text { Zelber-Sagi } \\
\text { et al. (2007) } \\
\text { [36] }\end{array}$ & Cross-sectional & $1 / 349$ & - & $\begin{array}{c}\text { Patients with or without } \\
\text { NAFLD }\end{array}$ & $\begin{array}{l}\text { The group with diagnosed NAFLD consumed almost } \\
\text { twice the amount of SSB. Intake of SSB was } \\
\text { significantly } \\
\text { associated with an increased risk for NAFLD. }\end{array}$ \\
\hline $\begin{array}{l}\text { Assy et al. } \\
(2008)[37]\end{array}$ & Cross-sectional & $1 / 61$ & 36 months & $\begin{array}{l}\text { Patients with NAFLD and } \\
\text { healthy control group }\end{array}$ & $\begin{array}{l}80 \% \text { of patients with NAFLD consumed an excessive } \\
\text { amount of SSB (more than } 50 \text { g/day of added sugar) } \\
\text { compared with } 20 \% \text { in healthy controls. SSB } \\
\text { consumption was the only independent variable that } \\
\text { was able to predict the presence of NAFLD. }\end{array}$ \\
\hline $\begin{array}{l}\text { Abid et al. } \\
\text { (2009) [38] }\end{array}$ & Prospective & $1 / 90$ & 6 months & $\begin{array}{l}\text { Patients with NAFLD and } \\
\text { healthy control group }\end{array}$ & $\begin{array}{l}80 \% \text { of patients with NAFLD had an excessive intake } \\
\text { of SSB ( }>500 \mathrm{~cm}^{3} / \text { day) compared to } 17 \% \text { of healthy } \\
\text { controls. Logistic regression analysis showed that SSB } \\
\text { consumption is a strong predictor of NAFLD } \\
\text { independent of metabolic syndrome and CRP level. }\end{array}$ \\
\hline $\begin{array}{l}\text { Abdelmalek } \\
\text { et al. }(2010) \\
{[39]}\end{array}$ & Cross-sectional & $1 / 427$ & 3 months & $\begin{array}{l}\text { Patients with NAFLD with } \\
\text { none, minimum to moderate, } \\
\text { and daily SSB and fruit juices } \\
\text { consumption }\end{array}$ & $\begin{array}{c}\text { Increased fructose consumption was associated with } \\
\text { hypertriglyceridemia, low HDL-c levels. } \\
\text { Daily fructose consumption was associated with lower } \\
\text { steatosis grade and higher fibrosis stage. } \\
\text { In older adults (age }>\text { or }=48 \text { years), daily fructose } \\
\text { consumption was associated with increased hepatic } \\
\text { inflammation and hepatocyte ballooning. }\end{array}$ \\
\hline $\begin{array}{l}\text { Maersk et al. } \\
\text { (2012) [40] }\end{array}$ & $\mathrm{RCT}$ & $1 / 47$ & 6 months & $\begin{array}{l}\text { Overweight patients for } 6 \\
\text { months consuming water, milk, } \\
\text { diet cola, and regular cola } \\
\text { (SSSD) }\end{array}$ & $\begin{array}{c}\text { Milk and diet cola reduced systolic blood pressure by } \\
10-15 \% \text { compared with regular cola. } \\
\text { Daily intake of SSSDs increased accumulation of: } \\
\text { liver fat, } \\
\text { skeletal muscle fat, visceral fat, } \\
\text { blood triglycerides, and total cholesterol, compared } \\
\text { with milk, diet cola, and water. }\end{array}$ \\
\hline $\begin{array}{l}\text { Chiu et al. } \\
\text { (2014) [41] }\end{array}$ & $\begin{array}{l}\text { Meta-analysis, } \\
\text { systematic review } \\
\text { of controlled trials }\end{array}$ & $13 / 260$ & $\begin{array}{l}\text { More than } 7 \\
\text { days }\end{array}$ & Healthy participants & $\begin{array}{l}\text { There was no effect of fructose in isocaloric trials. } \\
\text { Increased consumption of fructose in hypercaloric } \\
\text { trials increased both IHCL and ALT. }\end{array}$ \\
\hline
\end{tabular}


Table 1. Cont.

\begin{tabular}{|c|c|c|c|c|c|}
\hline $\begin{array}{l}\text { Authors } \\
\text { (Year) }\end{array}$ & Study Type & $\begin{array}{l}\text { Studies/ } \\
\text { Participants } \\
\text { (N) }\end{array}$ & $\begin{array}{l}\text { Average } \\
\text { Duration of } \\
\text { Follow-Up }\end{array}$ & Population & Findings \\
\hline $\begin{array}{l}\text { Chung et al. } \\
(2014)[42]\end{array}$ & $\begin{array}{c}\text { Meta-analysis, } \\
\text { systematic review } \\
\text { of observational } \\
\text { and interventional } \\
\text { studies }\end{array}$ & $27 / 1670$ & $\begin{array}{l}6 \text { days to } 6 \\
\text { months }\end{array}$ & $\begin{array}{c}\text { Patients with or without } \\
\text { NAFLD }\end{array}$ & $\begin{array}{l}\text { Observational studies were rated insufficient because } \\
\text { of the high risk of biases and inconsistent study } \\
\text { findings. } \\
\text { Hypercaloric fructose diet (supplemented by pure } \\
\text { fructose) increased liver fat and AST concentrations in } \\
\text { healthy men compared with the consumption of a } \\
\text { weight-maintenance diet with a low level of evidence. } \\
\text { Hypercaloric fructose and glucose diets have similar } \\
\text { effects on liver fat and liver enzymes in healthy adults, } \\
\text { also with a low level of evidence. }\end{array}$ \\
\hline $\begin{array}{l}\text { Hochuli } \\
\text { et al. }(2014) \\
\quad[43]\end{array}$ & $\begin{array}{l}\text { Randomized } \\
\text { crossover }\end{array}$ & $1 / 34$ & 3 weeks & $\begin{array}{l}\text { Healthy young men with } \\
\text { medium fructose, high } \\
\text { fructose, high sucrose, and } \\
\text { high glucose consumption for } \\
\quad 3 \text { weeks }\end{array}$ & $\begin{array}{l}\text { Fatty acid synthesis was increased after high fructose } \\
\text { consumption and medium fructose consumption } \\
\text { compared with high sucrose consumption, high } \\
\text { glucose consumption, or baseline. } \\
\text { Fasting palmitoylcarnitine was significantly increased } \\
\text { after high fructose and high sucrose consumption. }\end{array}$ \\
\hline $\begin{array}{l}\text { Jin et al. } \\
(2014)[44]\end{array}$ & $\mathrm{RCT}$ & $1 / 24$ & 4 weeks & $\begin{array}{l}\text { Overweight patients with } \\
\text { average self-reported } \\
\text { consumption of at least } 3 \\
\text { servings of SSB or fruit juice } \\
\text { divided into } 2 \text { groups: } \\
\text { consuming glucose only } \\
\text { beverages and fructose only } \\
\text { beverages }\end{array}$ & $\begin{array}{l}\text { There was no significant change in hepatic fat or body } \\
\text { weight in the group consuming glucose only or } \\
\text { fructose only beverages. In the glucose beverage } \\
\text { group, there was significantly improved adipose } \\
\text { insulin sensitivity, CRP, and LDL-c oxidation. }\end{array}$ \\
\hline $\begin{array}{l}\text { Ma et al. } \\
(2015)[45]\end{array}$ & Cross-sectional & $1 / 2634$ & 3 years & $\begin{array}{l}\text { Patients consuming SSB vs. } \\
\text { patients who did not consume } \\
\text { SSB }\end{array}$ & $\begin{array}{l}\text { Increased incidence of NAFLD was observed in } \\
\text { patients with daily consumption of SSB. } \\
\text { SSB consumption was positively associated with } \\
\text { increased ALT levels. }\end{array}$ \\
\hline $\begin{array}{l}\text { Schwarz } \\
\text { et al. }(2015) \\
{[29]}\end{array}$ & Prospective & $1 / 8$ & 9 days & $\begin{array}{l}\text { Healthy men on } \\
\text { weight-maintaining diets: high } \\
\text { in fructose vs. isocaloric diet } \\
\text { with complex carbohydrate } \\
\text { substituted for fructose }\end{array}$ & $\begin{array}{l}\text { Participants' weight remained stable. } \\
\text { A high fructose diet was associated with higher DNL } \\
\text { and higher liver fat in all participants. }\end{array}$ \\
\hline $\begin{array}{l}\text { Wijarnpreecha } \\
\text { et al. (2015) } \\
{[46]}\end{array}$ & $\begin{array}{l}\text { Meta-analysis, } \\
\text { systematic review } \\
\text { of cross-sectional } \\
\text { and cohort studies }\end{array}$ & $7 / 4639$ & $\begin{array}{l}6 \text { months to } \\
7 \text { years }\end{array}$ & $\begin{array}{l}\text { Patients consuming a } \\
\text { significant amount of either } \\
\text { sugar or SSB vs. patients who } \\
\text { did not consume SSB }\end{array}$ & $\begin{array}{l}\text { Patients consuming a significant amount of either } \\
\text { sugar or SSB have an increased risk of NAFLD. }\end{array}$ \\
\hline $\begin{array}{l}\text { Chen et al. } \\
\text { (2019) [47] }\end{array}$ & $\begin{array}{l}\text { Meta-analysis, } \\
\text { systematic review } \\
\text { of cross-sectional, } \\
\text { case-control and } \\
\text { cohort studies }\end{array}$ & $12 / 35,705$ & - & $\begin{array}{l}\text { Patients consuming low, } \\
\text { middle, and high doses of SSB }\end{array}$ & $\begin{array}{c}\text { Consumption of SSB was associated with an increased } \\
\text { risk of NAFLD. } \\
\text { Consumption of SSB had a dose-dependent effect on } \\
\text { the risk of NAFLD. }\end{array}$ \\
\hline
\end{tabular}

Abbreviations: ALT—alanine aminotransferase, AST—aspartate aminotransferase, CI-credible interval, CRP-Creactive protein, DNL—de novo lipogenesis, HDL-c-high-density lipoprotein cholesterol, LDL-c- low-density lipoprotein cholesterol, IHCL-intrahepatocellular lipids, NAFLD—non-alcoholic fatty liver disease, MD—mean difference, $\mathrm{OR}$ - odds ratio, RCT—randomized controlled trial, RR — risk ratio, SMD—standardized mean difference, SSB — sugar-sweetened beverages, SSSB — sucrose-sweetened soft drinks.

In a systematic review and meta-analysis of observational studies involving 4639 individuals, SSB consumption led to a 53\% increased risk of developing NAFLD in comparison to participants who did not ingest SSB [46]. Another analysis of 12 studies with 35,705 individuals showed that higher consumption of SBB was associated with a $40 \%$ increase in the incidence of NAFLD [47]. Other studies also reported increased risk of NAFLD associated with consumption of SBB $[36-40,43]$, yet some of the meta-analyses indicate the increase of intrahepatocellular lipids only under conditions of hypercaloric diet [41,42]. An interesting observation is that the association between SBB intake and liver fat may be independent of BMI [45]. One small RCT concluded that there was no significant change in hepatic fat or body weight in the groups consuming fructose or glucose beverages only; however, reduction of fructose led to improvement of several factors related to CVD [44]. What is also interesting to note is that fructose consumption influences the composition and function of gut microbiota in a way that promotes the development and progression of NAFLD [48]. 


\section{NAFLD and Gut Microbiota}

The pioneering studies using germ-free mice and gut microbiota transfer related to the association of gut microbiome with metabolic diseases revealed a contribution of gut microbiota to weight gain and metabolic alterations [49]. During the last decade, there has been a growing body of evidence demonstrating the contribution of the gut microbiome to the pathogenesis of NAFLD [50-52]. In general, dysfunction of the gut-liver axis caused by bacterial proliferation in the intestine, alteration of the intestinal permeability, and intestinal dysbiosis have a large influence on the development and progression of NAFLD [11]. Initial studies demonstrated that genetically modified mice (modification in the inflammasome pathway) were prone to develop NASH when co-housed with wild-type mice, leading to the development of liver steatosis and inflammation in wild-type mice as a consequence of microbiota sharing through coprophagia [53].

Fecal microbiota transfer from patients with NASH to germ-free mice causes hepatic steatosis and inflammation in these animals [54]. On the other hand, the outcomes of animal studies cannot be directly extrapolated to humans (e.g., mice do not develop the whole range of steatosis stages seen in humans, and mice microbiota itself differs from humans) [55,56].

Human studies have been based on comparisons of gut microbiota between patients with NAFLD, NASH, and cirrhosis and individuals with a healthy liver performed to demonstrate gut microbiota signatures in these pathological conditions [57]. Gut microbiota, and specifically, the gut-liver axis' role in the pathogenesis of NAFLD, has been explored in up-to-date studies, but this relationship is still poorly defined. Nevertheless, gut microbiome signatures in NAFLD, NAFLD fibrosis, and cirrhosis could become non-invasive diagnostic biomarkers for liver disease diagnosis [21].

The gut-liver axis is an association between gut microbiota and the liver. The interaction is conducted through the portal vein, which transports products from the gut to the liver and, in return, bile and antibodies from the liver to the intestine [58]. An important determining health factor seems to be a mucosal barrier comprised of intestinal epithelial cells. Its permeability and mucus composition are derived from gut microbiota and the presence of immune cells $[58,59]$. Increased permeability of the intestinal mucosal barrier and unfavorable changes in gut microbiota compositions are possible factors in the development and progression of NAFLD [58,59]. Dysfunction of gut microbiota results in the production of PAMPs (pathogen-associated molecular patterns), and increased permeability of the mucosal barrier leads to increased inflammation in the liver and the development and progression of liver disease [58-60]. Studies have shown a lower diversity of microbiota in patients with NAFLD compared to healthy controls [61,62].

Abnormalities of gut microbiota composition in stools of patients with NAFLD have been highlighted in a meta-analysis showing increased abundance of Escherichia, Prevotella, and Streptococcus and decreased abundance of Coprococcus, Feacalibacterium, and Ruminococcus [63]. When patients with liver fibrosis and patients with severe steatosis without fibrosis were compared, fecal Clostridium was significantly decreased in patients with liver fibrosis and was negatively associated with liver stiffness measurement (LSM) and myosteatosis [64]. Patients with liver fibrosis had increased fecal abundance of Escherichia and Shigella compared to patients with severe steatosis without fibrosis [64]. In another study in patients with NASH, there were increased levels of Escherichia and Shigella comparing patients with liver biopsy results as F0 (absence of fibrosis) or F1 (perisinusoidal or periportal fibrosis) [62].

NAFLD also results in increased fecal ester volatile organic compounds (VOC) and the presence of higher concentrations of fecal propionate and isobutyric acid and serum 2-hydroxybutyrate and L-lactic acid $[65,66]$. VOC is the result of gut microbiota substrate fermentation and is considered a potential marker of intestinal dysbiosis [67]. The results of the mentioned studies are summarized in Table 2. 
Table 2. Associations between NAFLD and gut microbiota.

\begin{tabular}{|c|c|c|c|c|c|}
\hline $\begin{array}{l}\text { Authors } \\
\text { (Year) }\end{array}$ & Study Type & $\begin{array}{l}\text { Studies/ } \\
\text { Participants } \\
\text { (N) }\end{array}$ & $\begin{array}{l}\text { Average } \\
\text { Duration of } \\
\text { Follow-Up }\end{array}$ & Population & Findings \\
\hline $\begin{array}{l}\text { Raman et al. } \\
(2013)[65]\end{array}$ & $\begin{array}{l}\text { Observational } \\
\text { case-control }\end{array}$ & $1 / 60$ & - & $\begin{array}{l}\text { Obese patients with NAFLD vs. } \\
\text { healthy control }\end{array}$ & $\begin{array}{l}\text { In the fecal microbiome of NAFLD patients, there was an } \\
\text { over-representation of Lactobacillus species and selected } \\
\text { members of phylum Firmicutes and increased fecal ester } \\
\text { VOC. }\end{array}$ \\
\hline $\begin{array}{l}\text { Wang et al. } \\
\text { (2016) [61] }\end{array}$ & $\begin{array}{l}\text { Cross- } \\
\text { sectional }\end{array}$ & $1 / 126$ & - & $\begin{array}{l}\text { Non-obese patients with } \\
\text { NAFLD vs. healthy control }\end{array}$ & $\begin{array}{l}\text { In non-obese patients with NAFLD, there was lower diversity } \\
\text { and a phylum-level change in microbiota compared to } \\
\text { healthy control. } \\
\text { NAFLD patients had } 20 \% \text { more phylum Bacteroidetes and } \\
24 \% \text { fewer Firmicutes compared to healthy control. }\end{array}$ \\
\hline $\begin{array}{l}\text { Shen et al. } \\
\text { (2017) [62] }\end{array}$ & $\begin{array}{l}\text { Cross- } \\
\text { sectional }\end{array}$ & $1 / 47$ & - & $\begin{array}{l}\text { Patients with NAFLD vs. } \\
\text { healthy control }\end{array}$ & $\begin{array}{l}\text { NAFLD patients had lower gut microbiota diversity than } \\
\text { healthy control. } \\
\text { In stools of patients with NASH, there were decreased levels } \\
\text { of Prevotella, increased levels of Blautia, Lachnospiraceae, } \\
\text { Escherichia, Shigella, and Enterobacteriacae compared to } \\
\text { patients with NAFLD. }\end{array}$ \\
\hline $\begin{array}{l}\text { Da Silva } \\
\text { et al. }(2018) \\
{[66]}\end{array}$ & $\begin{array}{l}\text { Cross- } \\
\text { sectional }\end{array}$ & $1 / 67$ & 7 days & $\begin{array}{c}\text { Patients with NAFLD, NASH } \\
\text { vs. healthy control }\end{array}$ & $\begin{array}{l}\text { In stools of NAFLD patients, Firmicutes, Bacteroidetes were } \\
\text { less abundant and Lactobacillaceae more abundant compared } \\
\text { to healthy control. } \\
\text { NAFLD patients had higher concentrations of fecal } \\
\text { propionate and isobutyric acid and serum 2-hydroxybutyrate } \\
\text { and L-lactic acid. }\end{array}$ \\
\hline $\begin{array}{l}\text { Lanthier } \\
\text { et al. }(2021) \\
{[64]}\end{array}$ & Prospective & $1 / 52$ & 3 months & $\begin{array}{l}\text { Obese adults with NAFLD: } \\
\text { patients with severe liver } \\
\text { steatosis vs. patients with } \\
\text { fibrosis }\end{array}$ & $\begin{array}{l}\text { Abundance of fecal Clostridium was significantly decreased } \\
\text { with the presence of liver fibrosis and was negatively } \\
\text { associated with liver stiffness measurement. } \\
\text { Escherichia and Shigella increased fecal abundance was } \\
\text { observed in patients with fibrosis compared to patients with } \\
\text { severe steatosis without fibrosis. }\end{array}$ \\
\hline $\begin{array}{l}\text { Li et al. } \\
\text { (2021) [63] }\end{array}$ & $\begin{array}{l}\text { Meta-analysis, } \\
\text { systematic } \\
\text { review }\end{array}$ & $15 / 1265$ & - & $\begin{array}{l}\text { Adults with NAFLD vs. } \\
\text { healthy control group }\end{array}$ & $\begin{array}{c}\text { Stools of patients with NAFLD exhibited an increased } \\
\text { abundance of Escherichia, } \\
\text { Prevotella, Streptococcus } \\
\text { and exhibited a decreased abundance of Coprococcus, } \\
\text { Faecalibacterium and Ruminococcus. } \\
\text { No significant difference in the abundance of Bacteroides, } \\
\text { Bifidobacterium, Blautia, Clostridium, Dorea, Lactobacillus, } \\
\text { Parabacteroides, or Roseburia. }\end{array}$ \\
\hline
\end{tabular}

Abbreviations: $\mathrm{CI}$-credible interval, NAFLD—non-alcoholic fatty liver disease, NASH—non-alcoholic steatohepatitis, SMD—standardized mean difference, VOC—volatile organic compounds.

\section{Treatment of NAFLD with Microbiome Alterations}

The aforementioned associations between NAFLD and gut microbiota have resulted in studies investigating the effects of microbiome alternation with probiotics, prebiotics, synbiotics, or fecal microbiota transplantation (FMT) on the clinical course of NAFLD with promising results [68-72].

According to the definitions formulated by the WHO and Food and Agriculture Organization of the United Nations (FAO), probiotics are live strains of strictly selected microorganisms which, when administered in adequate amounts, confer a health benefit on the host [73]. Prebiotics are described as a nonviable food component that confers a health benefit on the host associated with modulation of microbiota [74]. Synbiotics are the combination of synergistically acting probiotics and prebiotics; their role is the improvement of the survival of probiotic microorganisms in the gastrointestinal tract [75].

In this review article, we focus on the meta-analysis of RCT (randomized controlled trials), showing that probiotic/synbiotic therapy results in improving liver enzymes' activity and/or reduced steatosis/fibrosis in patients with NAFLD [68-71]. Moreover, treatment with probiotics decreases levels of CRP (C-reactive protein) and TNF- $\alpha$ (tumor necrosis factor $\alpha$ ), suggesting the reduction of inflammation and playing an important role in NAFLD pathogenesis $[68,70,72,76]$. The studies related to synbiotics in patients with NAFLD are limited. In a recent RCT, there was a reduction in steatosis and improved liver enzyme changes observed in patients treated with bifidobacterium animalis and insulin [77]. In another study, the use of synbiotics positively influenced inflammatory markers in NAFLD [78]. 
The role of FMT in patients with NAFLD has limited RCT evidence. FMT was first proven to be a good treatment method of antibiotic-resistant clostridium difficile infection in 2013 [79] and soon after was tested in other diseases, including metabolic diseases [80]. In an RCT including 21 patients undergoing allogenic or autologous FMT, the procedure was not associated with an improvement in insulin resistance nor hepatic proton density fat fraction but had the potential to lower small intestinal permeability [81]. In the study by Witjes et al., allogenic FMT using lean vegan donors modified gut microbiota composition with favorable changes in plasma metabolites and steatohepatitis [82]. The aforementioned studies are summarized in Table 3.

Table 3. Treatment of NAFLD with microbiome alternation.

\begin{tabular}{|c|c|c|c|c|c|}
\hline $\begin{array}{l}\text { Authors } \\
\text { (Year) }\end{array}$ & Study Type & $\begin{array}{l}\text { Studies/ } \\
\text { Participants } \\
\text { (N) }\end{array}$ & $\begin{array}{l}\text { Duration of } \\
\text { Treatment }\end{array}$ & Population & Findings \\
\hline Ma et al. (2013) [68] & $\begin{array}{l}\text { Meta-analysis of RCT } \\
\text { (probiotic vs. placebo) }\end{array}$ & $4 / 132$ & 8-24 weeks & $\begin{array}{l}\text { Adults with } \\
\text { NAFLD }\end{array}$ & $\begin{array}{l}\text { Probiotic therapy was associated with a significant } \\
\text { decrease in levels of ALT, AST, total cholesterol, } \\
\text { HDL-c, TNF- } \alpha \text {, and HOMA-IR. }\end{array}$ \\
\hline $\begin{array}{l}\text { Eslamparast et al. (2014) } \\
\text { [78] }\end{array}$ & $\begin{array}{c}\text { RCT } \\
\text { (synbiotic vs. placebo) }\end{array}$ & $1 / 52$ & 28 weeks & $\begin{array}{l}\text { Adults with } \\
\text { NAFLD }\end{array}$ & $\begin{array}{c}\text { In patients with NAFLD using synbiotic compared to } \\
\text { the placebo group, significantly decreased levels of } \\
\text { ALT, AST, GGT, CRP, TNF- } \alpha \text {, and fibrosis scores were } \\
\text { observed. }\end{array}$ \\
\hline Loman et al. (2018) [69] & $\begin{array}{l}\text { Meta-analysis of RCT } \\
\text { (probiotic or synbiotic or } \\
\text { prebiotic vs. placebo) }\end{array}$ & $25 / 1309$ & 2-28 weeks & $\begin{array}{l}\text { Adults with } \\
\text { NAFLD }\end{array}$ & $\begin{array}{l}\text { Probiotic/synbiotic/prebiotic therapies were } \\
\text { associated with significantly reduced levels of } \\
\text { ALT, AST, GGT, total cholesterol, LDL-c, and TAG, but } \\
\text { no significant difference in TNF- } \alpha \text { and CRP levels. }\end{array}$ \\
\hline $\begin{array}{l}\text { Bakhshimoghaddam } \\
\text { et al. (2018) [77] }\end{array}$ & $\begin{array}{l}\text { RCT } \\
\text { (synbiotic vs. control } \\
\text { group) }\end{array}$ & $1 / 102$ & 24 weeks & $\begin{array}{l}\text { Adults with } \\
\text { NAFLD }\end{array}$ & $\begin{array}{l}\text { Grades of NAFLD determined in ultrasound } \\
\text { examination significantly decreased in patients with } \\
\text { NAFLD consuming synbiotic, compared to } \\
\text { conventional and control groups. }\end{array}$ \\
\hline Khan et al. (2019) [70] & $\begin{array}{l}\text { Meta-analysis, systematic } \\
\text { review of RCT } \\
\text { (probiotic or synbiotic vs. } \\
\text { placebo) }\end{array}$ & $12 / 624$ & 8-24 weeks & $\begin{array}{l}\text { Adults with } \\
\text { NAFLD }\end{array}$ & $\begin{array}{l}\text { Probiotic/synbiotic therapies were associated with a } \\
\text { significant reduction in levels of ALT, AST, CRP, and } \\
\text { significant improvement in liver fibrosis score. }\end{array}$ \\
\hline $\begin{array}{l}\text { Sharpton et al. (2019) } \\
\text { [71] }\end{array}$ & $\begin{array}{l}\text { Meta-analysis of RCT } \\
\text { (probiotic or synbiotic vs. } \\
\text { placebo) }\end{array}$ & $21 / 1252$ & 8-28 weeks & $\begin{array}{l}\text { Adults with } \\
\text { NAFLD }\end{array}$ & $\begin{array}{l}\text { Probiotic/synbiotic therapies were associated with a } \\
\text { significant reduction in levels of } \\
\text { ALT and LSM. } \\
\text { Usage of probiotics/synbiotics was associated with } \\
\text { increased odds of improvement in hepatic steatosis. }\end{array}$ \\
\hline Craven et al. (2020) [81] & $\begin{array}{l}\text { RCT } \\
\text { (allogenic FMT vs. } \\
\text { autologous FMT) }\end{array}$ & $1 / 21$ & 6 months & $\begin{array}{l}\text { Adults with } \\
\text { NAFLD }\end{array}$ & $\begin{array}{l}\text { There were no significant differences between patients } \\
\text { with NAFLD after allogenic FMT and autologous FMT } \\
\text { in HOMA-IR or hepatic PDFF. } \\
\text { Allogenic FMT in patients with NAFLD with elevated } \\
\text { small intestine permeability at baseline caused a } \\
\text { significant reduction of small intestine permeability } 6 \\
\text { weeks after allogenic FMT. }\end{array}$ \\
\hline Pan et al. (2020) [72] & $\begin{array}{l}\text { Meta-analysis, systematic } \\
\text { review of RCT } \\
\text { (probiotic vs. placebo) }\end{array}$ & $19 / 954$ & & $\begin{array}{l}\text { Adults with } \\
\text { NAFLD }\end{array}$ & $\begin{array}{l}\text { Probiotic supplementation significantly decreased } \\
\text { TNF- } \alpha \text { and CRP levels. }\end{array}$ \\
\hline Witjes et al. (2020) [82] & $\begin{array}{c}\mathrm{RCT} \\
\text { (allogenic FMT vs. } \\
\text { autologous FMT) }\end{array}$ & $1 / 21$ & 24 weeks & $\begin{array}{l}\text { Adults with } \\
\text { NAFLD }\end{array}$ & $\begin{array}{l}\text { Allogenic FMT was associated with modified gut } \\
\text { microbiota composition (increased abundance of } \\
\text { ruminococcus, eubacterium hallii, faecalibacterium, and } \\
\text { prevotella copri), decreased levels of GGT, a trend } \\
\text { toward improvement in the necro-inflammation score } \\
\text { (consisting of both lobular inflammation and } \\
\text { hepatocellular ballooning). } \\
\text { There was no significant difference in fibrosis score } \\
\text { after allogenic FMT. }\end{array}$ \\
\hline
\end{tabular}

Abbreviations: ALT_alanine aminotransferase, AST-aspartate aminotransferase, CRP-C-reactive protein, CI-credible interval, GGT_-gamma-glutamyl transferase, HDL-c-high-density lipoprotein cholesterol, HOMAIR-homeostatic model assessment for insulin resistance, LDL-c-low-density lipoprotein cholesterol, LSM-liver stiffness measurement, NAFLD—non-alcoholic fatty liver disease, MD—mean difference, OR-odds ratio, RCTrandomized controlled trial, RR—relative risk, SAT—subcutaneous adipose tissue, SMD—standardized mean difference, T2DM - type 2 diabetes mellitus, TAG - triglyceride, TNF- $\alpha$ - tumor necrosis factor- $\alpha, \mathrm{WMD}-$ weighted mean difference.

\section{NAFLD and T2DM}

According to epidemiological data, the overall prevalence of NAFLD among patients with T2DM is $55.5 \%$, and NASH is $37.3 \%$; also, $17 \%$ of T2DM patients who underwent liver 
biopsy have advanced fibrosis [14]. Current guidelines emphasize the role of screening for diabetes in patients diagnosed with NAFLD and vice versa $[9,83]$. NAFLD itself increases the risk of T2DM incidence [84-86], and the risk of the new-onset T2DM is doubled in patients with NAFLD [87]. Moreover, 25\% of patients with NAFLD also have T2DM [88].

NAFLD and insulin resistance are interconnected, and therefore the development of prediabetes and diabetes is the most direct consequence of them at the extrahepatic level $[11,89]$. Particularly, the coexistence of NAFLD and T2DM worsens the course of both conditions since this relationship is bidirectional [90-92]. One meta-analysis found that the risk of T2DM is greater in patients with advanced NAFLD with fibrosis [84], and in another meta-analysis evaluating whether NAFLD predicted T2DM, NAFLD predicted the risk of T2DM independent of age and obesity, irrespective of the NAFLD diagnosis method (ultrasonography or elevated liver enzymes) [85]. Moreover, this observation was also applicable to patients with prediabetes and NAFLD, where the incidence of T2DM was higher than in patients with prediabetes without NAFLD [86]. When different types of diabetes were analyzed, the prevalence of NAFLD was low in patients with type 1 diabetes mellitus but high in T2DM patients in whom NAFLD was associated with increasing BMI, triglycerides, ALT (alanine aminotransferase) serum concentration, and decreasing adiponectin concentration [93]. Surprisingly, NAFLD occurred more often in T2DM patients not treated with insulin than in patients treated with insulin [93].

In another cohort study of 10,141 participants, future diabetes mellitus risk could be modified with time by changes in NAFLD status where resolution of NAFLD could diminish the risk of diabetes onset. On the other hand, the development of NAFLD raised the risk of developing diabetes [94]. Current evidence suggests that the magnitude of risk of incident T2DM mirrors the severity of NAFLD, especially with the severity of liver fibrosis [95].

It is important to distinguish between simple steatosis, which does not progress to advanced fibrosis, and non-alcoholic steatohepatitis (NASH), which can lead to hepatocellular carcinoma. Indeed, NASH is characterized by fat accumulation, inflammation and necrosis, ballooning of the cells, and different stages of liver fibrosis, up to cirrhosis. The only method to differentiate between steatosis and NASH is liver biopsy. Masarone et al. performed this invasive procedure in 215 patients with elevated transaminases and metabolic syndrome or T2DM. The prevalence of NAFLD in patients with metabolic syndrome was $94.82 \%$ and was present in all the patients with T2DM. NASH was found in $58.52 \%$ of participants with metabolic syndrome and $96.82 \%$ of T2DM patients. According to the authors, one can assume that patients with T2DM have NASH. As insulin resistance is of crucial importance in the pathophysiology of both T2DM and NASH, NASH may be one of the early complications of T2DM [96].

Some studies have reported that a reduction in the T2DM incidence [97] and the clinical manifestation of atherosclerosis [98] could be achieved by the pharmacological eradication of the hepatitis C virus with direct-acting antiviral drugs [99], caused by the reduction of insulin resistance and improving various HCV-induced glucose homeostasis mechanisms $[97,98]$.

The strong link between T2DM and NAFLD was underlined in 2020 by an international panel of experts who proposed the new term MAFLD instead of NAFLD [10]. The results of the studies described above are presented in Table 4. 
Table 4. NAFLD and T2DM.

\begin{tabular}{|c|c|c|c|c|c|}
\hline Authors (Year) & Study Type & $\begin{array}{l}\text { Studies/ } \\
\text { Participants } \\
\text { (N) }\end{array}$ & $\begin{array}{l}\text { Average } \\
\text { Duration of } \\
\text { Follow-Up }\end{array}$ & Population & Findings \\
\hline $\begin{array}{l}\text { Lalukka et al. } \\
\text { (2016) [85] }\end{array}$ & $\begin{array}{l}\text { Meta-analysis of } \\
\text { systematic review, } \\
\text { prospective studies }\end{array}$ & $20 / 122,517$ & $2-20$ years & $\begin{array}{l}\text { Adults with } \\
\text { NAFLD without } \\
\text { T2DM }\end{array}$ & $\begin{array}{l}\text { NAFLD predicted the risk of T2DM in all studies. } \\
\text { NAFLD predicted the risk of T2DM in all studies with } \\
\text { NAFLD diagnosis based on ultrasonography } \\
\text { independently of age. } \\
\text { NAFLD predicted the risk of T2DM in } 12 \text { of } 14 \text { studies } \\
\text { with NAFLD diagnosis based on liver function tests } \\
\text { independently of age or BMI. }\end{array}$ \\
\hline $\begin{array}{l}\text { Cusi et al. (2017) } \\
\text { [93] }\end{array}$ & Observational & $1 / 204$ & - & $\begin{array}{l}\text { Adults with T1DM } \\
\text { and T2DM with or } \\
\text { without NAFLD }\end{array}$ & $\begin{array}{l}\text { The prevalence of NAFLD in T1DM patients was low } \\
(8.8 \%) \text { but high in T2DM patients not treated with } \\
\text { insulin }(75.6 \%) \text { and treated with insulin }(61.7 \%) \text {. }\end{array}$ \\
\hline $\begin{array}{l}\text { Mantovani et al. } \\
\text { (2018) [84] }\end{array}$ & $\begin{array}{c}\text { Meta-analysis of } \\
\text { observational studies }\end{array}$ & $19 / 296,439$ & $\begin{array}{l}\text { at least } \\
5 \text { years }\end{array}$ & $\begin{array}{l}\text { Adults with } \\
\text { NAFLD, without } \\
\text { T2DM }\end{array}$ & $\begin{array}{l}\text { Patients with NAFLD had a greater risk of T2DM } \\
\text { incidence. Patients with advanced NAFLD with } \\
\text { fibrosis had an even greater risk of T2DM incidence. }\end{array}$ \\
\hline $\begin{array}{c}\text { Cho et al. (2019) } \\
\text { [94] }\end{array}$ & Cohort & $1 / 2726$ & $\begin{array}{l}\text { 12-135 } \\
\text { months }\end{array}$ & $\begin{array}{l}\text { Adults with or } \\
\text { without NAFLD or } \\
\text { T2DM }\end{array}$ & $\begin{array}{l}\text { Incident and persistent NAFLD increased risk of } \\
\text { T2DM development. }\end{array}$ \\
\hline $\begin{array}{c}\text { Lee et al. (2019) } \\
\text { [86] }\end{array}$ & Cohort & $1 / 6240$ & $\begin{array}{c}4.30 \pm \\
1.91 \text { years }\end{array}$ & $\begin{array}{l}\text { Adults with } \\
\text { prediabetes with or } \\
\text { without NAFLD } \\
\text { from Korea }\end{array}$ & $\begin{array}{c}\text { The prevalence of NAFLD was } 45.4 \% \text {. During } \\
\text { follow-up, the incidence of T2DM was } 8.1 \% \text {. } \\
\text { Subjects with prediabetes and NAFLD had a higher } \\
\text { prevalence of T2DM. }\end{array}$ \\
\hline $\begin{array}{l}\text { Younossi et al. } \\
\text { (2019) [14] }\end{array}$ & $\begin{array}{l}\text { Meta-analysis, systematic } \\
\text { review of cross-sectional } \\
\text { and longitudinal studies }\end{array}$ & $80 / 49,419$ & $\begin{array}{l}\text { median } \\
3 \text { years }\end{array}$ & $\begin{array}{l}\text { Adults with T2DM } \\
\text { with or without } \\
\text { NAFLD and NASH }\end{array}$ & $\begin{array}{c}\text { The global prevalence of NAFLD was } 55.5 \% \text {. } \\
\text { The highest prevalence of NAFLD reported in studies } \\
\text { from Europe was } 68 \% \text {. } \\
\text { The global prevalence of NASH was } 37.3 \% \text {. } \\
\text { The prevalence of advanced fibrosis in patients with } \\
\text { NAFLD and T2DM was } 17 \% \text {. }\end{array}$ \\
\hline $\begin{array}{l}\text { Mantovani et al. } \\
\text { (2021) [95] }\end{array}$ & $\begin{array}{l}\text { Meta-analysis of } \\
\text { prospective studies }\end{array}$ & $33 / 501,022$ & at least 1 year & $\begin{array}{l}\text { Adults with } \\
\text { NAFLD }\end{array}$ & $\begin{array}{l}\text { Patients with NAFLD had a higher risk of incident DM } \\
\text { The risk increased across the severity of NAFLD. }\end{array}$ \\
\hline
\end{tabular}

Abbreviations: CI-credible interval, DM-diabetes mellitus, HR-hazard ratio, NAFLD-non-alcoholic fatty liver disease, NASH—non-alcoholic steatohepatitis, RR—risk ratio, T1DM—type 1 diabetes mellitus, T2DM-type 2 diabetes mellitus.

\section{Treatment of NAFLD with Antidiabetic Drugs}

Currently, there is no single, independent of the presence or absence of T2DM, pharmaceutical treatment for NAFLD that has been approved by international guidelines [9]. The frequent coexistence of diabetes and NAFLD and complex pathogenesis of these two metabolic diseases result in the growing interest in antidiabetic drugs used in the treatment of NAFLD.

The best documented direct beneficial effect remains assigned to pioglitazone [100-103], yet incretin drugs [104-122] seem to present favorable action via indirect modifications of metabolic risk factors and direct course of action with the most promising combination of glucagon-like peptide-1 receptor agonist (GLP-1 RA) and agonist of glucose-dependent insulinotropic polypeptide (GIP) [123].

Current guidelines state that pharmacotherapy is reserved for patients with NASH and for patients at high risk of disease progression. Among the antidiabetic drugs recommended, only pioglitazone is used for the treatment of NASH with insulin resistance (evidence level A, strength 2) $[9,124]$. Older studies showed that NASH treatment with pioglitazone caused histological improvement of hepatic steatosis and fibrosis [100-103]. In an RCT analyzing patients with T2DM or prediabetes and NASH, pioglitazone usage for 18-months resulted in a reduction of fibrosis score and hepatic triglyceride content and improved insulin sensitivity of adipose tissue, liver, and muscles [103]. In a recent meta-analysis, pioglitazone treatment in patients with NAFLD with or without T2DM caused significant reductions of ALT and AST (aspartate aminotransferase) levels [104].

Two relatively new antidiabetic drug classes, namely SGLT-2i (sodium-glucose cotransporter type-2 inhibitors) [105,114-117] and GLP-1 RA [104,106-112,118-122] show promise in the treatment of NAFLD/NASH patients with T2DM and have been added to the revised guidelines from the year 2020 (evidence level C, strength 2) [124]. Revised guidelines indicate that both SGLT-2i and GLP-1 RA improved liver enzymes and histological findings [124]. The latest meta-analyses of the effects of SGLT-2i [113] and GLP-1 
RA [125] in NAFLD patients with T2DM, respectively, were published. In the study related to SGLT-2i, canagliflozin improved liver function parameters while dapagliflozin was better in improving glycemia and insulin sensitivity [113]. In the meta-analysis of GLP-1-RA, there was strong evidence that GLP-1 RA improved liver function and histology [125].

An upcoming drug of huge interest is a dual GIP and GLP-1 RA agent (tirzepatide), which is under investigation. It is being administered once a week in the therapy of T2DM patients with NASH and fibrosis [123]. Treatment with this drug for 26 weeks compared to dulaglutide and placebo resulted in a significant reduction in NASH-related biomarkers, an increase in adiponectin, and a greater reduction of ALT, compared to dulaglutide treatment [123]. A published network meta-analysis of RCTs [126] assessed the effectiveness of antidiabetic medications for T2DM as potential therapeutic agents for NAFLD, comparing SGLT-2i, GLP-1 RA, PPAR $\gamma$ (peroxisome proliferator-activated receptor) agonists, biguanides, sulfonylureas, and insulin. This showed that GLP-1 RA and SGLT-2i led to reductions in BMI, fibrosis, and steatosis, with SGLT-2i being the best treatment for reducing low-density lipoprotein cholesterol (LDL-C) and rising HDL-C. Studies related to the SGLT-2i, GLP-1 RA, and dual GIP and GLP-1-RA use in the treatment of NAFLD are summarized in Table 5.

Table 5. NAFLD and NASH treatment with antidiabetic drugs.

\begin{tabular}{|c|c|c|c|c|c|}
\hline $\begin{array}{l}\text { Authors } \\
\text { (Year) }\end{array}$ & Study Type & $\begin{array}{l}\text { Studies/ } \\
\text { Participants } \\
\text { (N) }\end{array}$ & $\begin{array}{l}\text { Duration of } \\
\text { Treatment }\end{array}$ & Population & Findings \\
\hline $\begin{array}{l}\text { Boettcher } \\
\text { et al. }(2012) \\
\text { [102] }\end{array}$ & $\begin{array}{c}\text { Meta-analysis of RCT } \\
\text { (pioglitazone vs. placebo) }\end{array}$ & $4 / 334$ & 24-96 weeks & $\begin{array}{l}\text { T2DM patients with } \\
\text { NASH }\end{array}$ & $\begin{array}{l}\text { Pioglitazone treatment was associated with } \\
\text { histological improvement of ballooning } \\
\text { degeneration, } \\
\text { lobular inflammation, and steatosis compared to } \\
\text { placebo. }\end{array}$ \\
\hline $\begin{array}{l}\text { Eguchi et al. } \\
\text { (2015) [114] }\end{array}$ & $\begin{array}{l}\text { Prospective } \\
\text { (liraglutide vs. lifestyle } \\
\text { modification) }\end{array}$ & $1 / 26$ & 24 weeks & $\begin{array}{l}\text { Adults with NASH, BMI } \\
\geq 25 \mathrm{~kg} / \mathrm{m}^{2}, \text { with or } \\
\text { without T2DM }\end{array}$ & $\begin{array}{l}\text { Liraglutide treatment improved histological features } \\
\text { of steatohepatitis and fibrosis in } 80 \% \text { of patients and } \\
\text { aminotransferase levels in } 78.9 \% \text { of patients. }\end{array}$ \\
\hline $\begin{array}{l}\text { Rizvi et al. } \\
\text { (2015) [115] }\end{array}$ & $\begin{array}{l}\text { Prospective } \\
\text { (liraglutide and metformin } \\
\text { therapy vs. metformin } \\
\text { therapy) }\end{array}$ & $1 / 58$ & 8 months & $\begin{array}{l}\text { Two groups of T2DM } \\
\text { patients with or without } \\
\text { NAFLD }\end{array}$ & $\begin{array}{l}\text { Carotid IMT decreased significantly in T2DM } \\
\text { patients with NAFLD but not in T2DM patients } \\
\text { without NAFLD. }\end{array}$ \\
\hline $\begin{array}{l}\text { Armstrong } \\
\text { et al. (2016) } \\
{[116]}\end{array}$ & RCT (liraglutide vs. placebo) & $1 / 52$ & 48 weeks & $\begin{array}{l}\text { Adults with NASH, BMI } \\
\geq 25 \mathrm{~kg} / \mathrm{m}^{2}, \text { with or } \\
\text { without T2DM }\end{array}$ & $\begin{array}{l}\text { Treatment with liraglutide was associated with } \\
\text { histological improvement of steatohepatitis. }\end{array}$ \\
\hline $\begin{array}{l}\text { Armstrong } \\
\text { et al. (2016) } \\
\text { [117] }\end{array}$ & $\begin{array}{c}\mathrm{RCT} \\
\text { (liraglutide vs. placebo) }\end{array}$ & $1 / 14$ & 12 weeks & $\begin{array}{l}\text { Adults with NASH, BMI } \\
\geq 25 \mathrm{~kg} / \mathrm{m}^{2} \text {, with or } \\
\text { without T2DM }\end{array}$ & $\begin{array}{l}\text { Liraglutide treatment was associated with } \\
\text { significant reduction of ALT, increased hepatic } \\
\text { insulin sensitivity, suppression of hepatic } \\
\text { endogenous glucose production with low-dose } \\
\text { insulin, a decrease of hepatic de novo lipogenesis. }\end{array}$ \\
\hline $\begin{array}{l}\text { Cusi et al. } \\
\text { (2016) [103] }\end{array}$ & $\begin{array}{c}\text { RCT } \\
\text { (pioglitazone vs. placebo) }\end{array}$ & $1 / 101$ & 18 months & $\begin{array}{l}\text { Patients with prediabetes } \\
\text { or T2DM and NASH }\end{array}$ & $\begin{array}{l}\text { Pioglitazone treatment was associated with } \\
\text { histological improvement of fibrosis score, } \\
\text { reduced hepatic triglyceride content and improved } \\
\text { insulin sensitivity of adipose tissue, liver, and } \\
\text { muscles. }\end{array}$ \\
\hline $\begin{array}{l}\text { Feng et al. } \\
(2017) \text { [109] }\end{array}$ & $\begin{array}{l}\text { RCT } \\
\text { (liraglutide vs. metformin } \\
\text { and gliclazide) }\end{array}$ & $1 / 85$ & 24 weeks & $\begin{array}{l}\text { T2DM patients with } \\
\text { NAFLD }\end{array}$ & $\begin{array}{l}\text { Liraglutide or metformin monotherapy was } \\
\text { associated with greater weight loss, reduction in } \\
\text { body fat mass, and improved glucose control } \\
\text { compared to gliclazide. Weight loss, fat mass, and } \\
\text { waist reduction affected favorably hepatic function } \\
\text { IHF decreased significantly after liraglutide. }\end{array}$ \\
\hline $\begin{array}{l}\text { Seko et al. } \\
\text { (2017) [110] }\end{array}$ & $\begin{array}{l}\text { Retrospective study } \\
\text { (all patients dulaglutide) }\end{array}$ & $1 / 15$ & 12 weeks & $\begin{array}{l}\text { T2DM patients with } \\
\text { biopsy-proven NAFLD }\end{array}$ & $\begin{array}{l}\text { Dulaglutide treatment was associated with } \\
\text { significantly decreased BMI, ALT, AST, } \mathrm{HbA}_{1 \mathrm{c}} \\
\text { levels. }\end{array}$ \\
\hline $\begin{array}{l}\text { Cusi et al. } \\
(2018)[110]\end{array}$ & $\begin{array}{l}\text { A post hoc analysis of } \\
\text { AWARD program } \\
\text { (dulaglutide vs. placebo) }\end{array}$ & $4 / 1499$ & 6 months & $\begin{array}{l}\text { T2DM patients with } \\
\text { NAFLD }\end{array}$ & $\begin{array}{l}\text { Dulaglutide treatment was associated with a } \\
\text { significant decrease in ALT, AST, and GGT } \\
\text { consistent with liver fat reduction. }\end{array}$ \\
\hline $\begin{array}{l}\text { Kuchay et al. } \\
(2018)[108]\end{array}$ & $\begin{array}{c}\mathrm{RCT} \\
\text { (empaglifozin vs. standard } \\
\text { treatment) }\end{array}$ & $1 / 50$ & 20 weeks & $\begin{array}{l}\text { T2DM patients with } \\
\text { NAFLD }\end{array}$ & $\begin{array}{l}\text { Empagliflozin treatment was associated with } \\
\text { significant liver fat reduction and ALT activity } \\
\text { improvement compared to the control group. }\end{array}$ \\
\hline $\begin{array}{l}\text { Shibuya } \\
\text { et al. (2018) } \\
\text { [105] }\end{array}$ & $\begin{array}{l}\text { RCT } \\
\text { (luseogliflozin vs. } \\
\text { metformin) }\end{array}$ & $1 / 32$ & 24 weeks & $\begin{array}{l}\text { T2DM patients with } \\
\text { NAFLD }\end{array}$ & $\begin{array}{l}\text { Luseogliflozin was associated with significantly } \\
\text { greater liver fat reduction than metformin and a } \\
\text { significantly greater decrease in VAT and BMI. }\end{array}$ \\
\hline
\end{tabular}


Table 5. Cont.

\begin{tabular}{|c|c|c|c|c|c|}
\hline $\begin{array}{l}\text { Authors } \\
\text { (Year) }\end{array}$ & Study Type & $\begin{array}{l}\text { Studies/ } \\
\text { Participants } \\
\text { (N) }\end{array}$ & $\begin{array}{l}\text { Duration of } \\
\text { Treatment }\end{array}$ & Population & Findings \\
\hline $\begin{array}{l}\text { Shimizu } \\
\text { et al. (2019) } \\
\text { [109] }\end{array}$ & $\begin{array}{c}\text { RCT } \\
\text { (dapagliflozin vs. control } \\
\text { group) }\end{array}$ & $1 / 57$ & 24 weeks & $\begin{array}{l}\text { T2DM patients with } \\
\text { NAFLD }\end{array}$ & $\begin{array}{l}\text { Dapagliflozin treatment was associated with a } \\
\text { significant decrease in CAP and } \\
\text { with a greater significant decrease in ALT and VAT. }\end{array}$ \\
\hline $\begin{array}{l}\text { Aso et al. } \\
(2019)[106]\end{array}$ & $\begin{array}{c}\text { RCT } \\
\text { (dapagliflozin vs. control } \\
\text { group) }\end{array}$ & $1 / 57$ & 24 weeks & $\begin{array}{l}\text { T2DM patients with } \\
\text { NAFLD }\end{array}$ & $\begin{array}{l}\text { Dapagliflozin was associated with a significant } \\
\text { decrease in VAT, SAT, ALT, AST, and GGT. }\end{array}$ \\
\hline $\begin{array}{l}\text { Yan et al. } \\
\text { (2019) [120] }\end{array}$ & $\begin{array}{c}\text { RCT } \\
\text { (liraglutide vs. sitagliptin vs. } \\
\text { insulin glargine) }\end{array}$ & $1 / 75$ & 26 weeks & $\begin{array}{l}\text { T2DM patients with } \\
\text { NAFLD under inadequate } \\
\text { glycemic control by } \\
\text { metformin }\end{array}$ & $\begin{array}{l}\text { Liraglutide treatment was associated with a } \\
\text { significant decrease in MRI-PDFF, VAT, SAT, and } \\
\text { body weight. } \\
\text { Sitagliptin treatment was associated with a } \\
\text { significant decrease in MRI-PDFF, VAT, and body } \\
\text { weight. }\end{array}$ \\
\hline $\begin{array}{l}\text { Hartman } \\
\text { et al. }(2020) \\
\quad[123]\end{array}$ & $\begin{array}{c}\text { RCT } \\
\text { (tirzepatide vs. dulaglutide } \\
\text { vs. placebo) }\end{array}$ & $1 / 316$ & 26 weeks & $\begin{array}{l}\text { T2DM patients with } \\
\text { NASH and fibrosis }\end{array}$ & $\begin{array}{l}\text { Tirzepatide treatment was associated with a greater } \\
\text { decrease in ALT level than dulaglutide treatment. } \\
\text { Adiponectin level increased significantly compared } \\
\text { to placebo, but not with dulaglutide therapy. }\end{array}$ \\
\hline $\begin{array}{l}\text { Kuchay et al. } \\
(2020)[121]\end{array}$ & $\begin{array}{c}\text { RCT } \\
\text { (dulaglutide vs. control } \\
\text { group) }\end{array}$ & $1 / 88$ & 24 weeks & $\begin{array}{l}\text { T2DM patients with } \\
\text { NAFLD }\end{array}$ & $\begin{array}{l}\text { Dulaglutide treatment was associated with a 2.6-fold } \\
\text { reduction of LFC and reduction of GGT levels. }\end{array}$ \\
\hline $\begin{array}{l}\text { Lai et al. } \\
\text { (2020) [107] }\end{array}$ & $\begin{array}{l}\text { Prospective, pilot study } \\
\text { (empagliflozin vs. placebo) }\end{array}$ & $1 / 39$ & 24 weeks & $\begin{array}{l}\text { T2DM patients with or } \\
\text { without NASH }\end{array}$ & $\begin{array}{l}\text { Empagliflozin treatment improved steatosis, } \\
\text { ballooning, and fibrosis. }\end{array}$ \\
\hline $\begin{array}{l}\text { Ghosal et al. } \\
(2021) \text { [125] }\end{array}$ & $\begin{array}{l}\text { Meta-analysis, systematic } \\
\text { review of RCT (GLP-1 RA vs. } \\
\text { placebo) }\end{array}$ & $8 / 615$ & 12-72 weeks & $\begin{array}{l}\text { T2DM patients with } \\
\text { NAFLD }\end{array}$ & $\begin{array}{l}\text { GLP-1 RA significantly reduced ALT, AST, GGT } \\
\text { levels, LFC, } \mathrm{HbA}_{1 \mathrm{c}} \text { levels, and body weight. } \\
\text { GLP-1 RA caused significant improvement of } \\
\text { NAFLD in biopsy. }\end{array}$ \\
\hline $\begin{array}{l}\text { Lee et al. } \\
(2021)[122]\end{array}$ & $\begin{array}{l}\text { Meta-analysis, systematic } \\
\text { review of RCT } \\
\text { (canagliflozin or } \\
\text { dapagliflozin vs. placebo) }\end{array}$ & $8 / 5984$ & $12-18$ weeks & $\begin{array}{l}\text { T2DM patients with } \\
\text { NAFLD }\end{array}$ & $\begin{array}{c}\text { Canagliflozin significantly reduced GGT levels. } \\
\text { Dapagliflozin significantly reduced } \mathrm{HbA} 1_{\mathrm{c}} \text { levels } \\
\text { and HOMA-IR. }\end{array}$ \\
\hline $\begin{array}{l}\text { Lian et al. } \\
(2021)[104]\end{array}$ & $\begin{array}{l}\text { Meta-analysis of RCT } \\
\text { (metformin or liraglutide or } \\
\text { pioglitazone vs. placebo) }\end{array}$ & $26 / ? ?$ & 12-96 weeks & $\begin{array}{l}\text { Patients with NAFLD and } \\
\text { with or without T2DM }\end{array}$ & $\begin{array}{l}\text { Pioglitazone had a significant effect on the levels of } \\
\text { ALT and AST but was also associated with an } \\
\text { increased risk of weight gain and increased BMI. } \\
\text { Liraglutide and metformin had significant effects on } \\
\text { reducing ALT and AST. }\end{array}$ \\
\hline $\begin{array}{l}\text { Mantovani } \\
\text { et al. }(2021) \\
{[111]}\end{array}$ & $\begin{array}{l}\text { Meta-analysis of RCT } \\
\text { (liraglutide or semaglutide } \\
\text { vs. placebo) }\end{array}$ & $22 / 936$ & $\begin{array}{l}\text { median } 26 \\
\text { weeks }\end{array}$ & $\begin{array}{l}\text { Overweight or obese } \\
\text { patients with NASH or } \\
\text { NAFLD with or without } \\
\text { T2DM }\end{array}$ & $\begin{array}{c}\text { Treatment with GLP-1 RA decreased LFC measured } \\
\text { by MRI, decreased ALT, GGT, but not AST levels, } \\
\text { and greater histological resolution without } \\
\text { worsening of liver fibrosis. }\end{array}$ \\
\hline $\begin{array}{l}\text { Newsome } \\
\text { et al. }(2021) \\
{[112]}\end{array}$ & $\begin{array}{c}\text { RCT } \\
\text { (semaglutide vs. placebo) }\end{array}$ & $1 / 320$ & 72 weeks & $\begin{array}{l}\text { Patients with NASH and } \\
\text { biopsy confirmed fibrosis }\end{array}$ & $\begin{array}{l}\text { After semaglutide treatment, NASH resolution was } \\
\text { achieved in } 36-59 \% \text { of patients with improvement in } \\
\text { fibrosis stage in } 43 \% \text { of them. }\end{array}$ \\
\hline $\begin{array}{l}\text { Ng et al. } \\
(2021)[126]\end{array}$ & $\begin{array}{l}\text { Meta-analysis of RCT } \\
\text { (PPAR } \gamma \text { agonists or SGLT-2i } \\
\text { vs. placebo) }\end{array}$ & $14 / ? ?$ & - & $\begin{array}{l}\text { T2DM patients with } \\
\text { NAFLD }\end{array}$ & $\begin{array}{l}\text { PPAR } \gamma \text { agonists and SGLT-2i significantly reduced } \\
\text { steatosis. } \\
\text { SGLT-2i resulted in a significantly greater reduction } \\
\text { of fibrosis compared to PPAR } \gamma \text {. }\end{array}$ \\
\hline $\begin{array}{l}\text { Song et al. } \\
(2021)[13]\end{array}$ & $\begin{array}{l}\text { Meta-analysis of RCT } \\
\text { (liraglutide vs. pioglitazone } \\
\text { vs. insulin vs. placebo) }\end{array}$ & $11 / 535$ & 12-24 weeks & $\begin{array}{l}\text { T2DM patients with } \\
\text { NAFLD }\end{array}$ & $\begin{array}{l}\text { Liraglutide decreased LFC, BMI, HDL-c, LDL-c, } \\
\qquad \mathrm{HbA}_{1 \mathrm{c}}, \mathrm{TC} \text {, and TAG. }\end{array}$ \\
\hline
\end{tabular}

Abbreviations: ALT—alanine aminotransferase, AST—aspartate aminotransferase, BMI—body mass index, CAP_ controlled attenuation parameter, $\mathrm{CI}$-credible interval, IHF-intrahepatic fat, GLP-1 RA—glucagon-like peptide 1 receptor agonists, GGT—gamma-glutamyl transferase, $\mathrm{HbA}_{1 \mathrm{c}}$ - glycated haemoglobin A1c, HDL-c- high density lipoprotein cholesterol, HOMA-IR-homeostatic model assessment for insulin resistance, LDL-c- low density lipoprotein cholesterol, LFC — liver fat content, LSM - liver stiffness measurement, MD—mean difference, $\mathrm{mg}$ milligram, MRI — magnetic resonance imaging, MRI-PDFF—-magnetic resonance imaging derived proton density fat fraction, NAFLD - non-alcoholic fatty liver disease, NASH - non-alcoholic steatohepatitis, OR - odds ratio, $\operatorname{PPAR} \gamma$ - peroxisome proliferator-activated receptor, RCT—randomized controlled trial, RR — relative risk, SAT— subcutaneous adipose tissue, SGLT-2i—sodium-glucose cotransporter type-2 inhibitors, SMD—standardized mean difference, T2DM-type 2 diabetes mellitus, TAG—triglycerides, TC—-total cholesterol, VAT—visceral adipose tissue, WMD—weighted mean difference.

\section{NAFLD and Cardiovascular Disease}

Both NAFLD and CVD are highly prevalent and associated with metabolic disturbances; hence they frequently coexist [127]. This causal relationship may be due to shared common pathophysiological pathways, which include low-grade inflammation, oxidative stress, and insulin resistance [128]. 
NAFLD is linked with different manifestations of CVD, including subclinical atherosclerosis, overt atherosclerosis, and cardiovascular events and deaths [24,129-131]. Hence, both the American Association for the Study of Liver Disease and the European Association for the Study of the Liver suggest cardiovascular screening in patients with NAFLD [9,132]. In relation to the association of NAFLD with the risk of major adverse cardiovascular events (MACE), several meta-analyses and cohort studies show that in patients with NAFLD, the risk of MACE is increased, independent of other cardiovascular risk factors or the extent of coronary disease [133,134].

One meta-analysis from the year 2021 deserves special attention because it was performed among people with histologically confirmed NAFLD who did not present with CVD at baseline (10,422 participants) and were prospectively followed-up for a median of 13.6 years [134]. This study showed that patients with biopsy-proven NAFLD who were matched to controls had a higher incidence of MACE, which included ischemic heart disease, congestive heart failure, and cardiovascular mortality [134]. Moreover, the rates of incident MACE increased progressively with worsening NAFLD severity.

There are also studies that indicated that CVD risks in patients with NAFLD who are non-obese [135] or non-overweight [136] were also increased. Additionally, in obese patients with NAFLD, liver fat content (LFC) $>10 \%$ was also a predictor of subclinical atherosclerosis [135].

One retrospective, "real world" cohort study aimed to describe the CVD burden and mortality in patients with NAFLD during 14-years follow-up observation following hospital discharge, showing that in patients with non-cirrhotic NAFLD, the condition was associated with increased overall mortality [137]. In contrast, other studies have stated that NAFLD was not correlated with CVD mortality [138-140] nor an increased risk of acute myocardial infarction or stroke [141].

Due to the recent change in nomenclature of fatty liver disease (NAFLD to MAFLD), the prevalence of fatty liver disease and associated CVD risk required re-evaluation, taking into account each of these definitions separately [142]. An analysis of 9,584,399 participants aged 40-64 from the National Health Database revealed that MAFLD and NAFLD, independent of the definition used, increased the risk of CVD events [142]. Furthermore, CVD seems to be increased when NAFLD coexists with T2DM. A meta-analysis of 11 studies, including cross-sectional and cohort studies, indicated that the risk for CVD in T1DM and T2DM patients with NAFLD was increased two-fold compared to patients without NAFLD [143]. In T2DM patients with NAFLD, the occurrence of coronary artery disease (CAD) was more prevalent than in T2DM patients without NAFLD [144-146]. Interestingly, patients diagnosed with NAFLD before T2DM diagnosis showed a higher prevalence of CAD and hypertension when compared to groups of patients with T2DM without NAFLD and T2DM diagnosed before NAFLD [144]. Additionally, T2DM patients with NAFLD had a higher prevalence of hypertension, obesity, higher hemoglobin A1c (HbA1c) levels, higher triglyceride, lower HDL-C concentration, and higher mean carotid IMT (intima-media thickness) [145].

On the other hand, another study concerning atherosclerotic lesions in T2DM patients found no significant difference in carotid IMT between T2DM patients with and without NAFLD [147]. The same study demonstrated that the prevalence of carotid and lower limb atherosclerotic plaque and stenosis was higher in T2DM patients with NAFLD compared to T2DM patients without NAFLD [147]. A study by Kim et al. divided T2DM patients into two groups: insulin-resistant and insulin-sensitive, whereby mean carotid IMT was higher in subjects with both insulin resistance and NAFLD than in insulin-sensitive patients with or without NAFLD [148]. T2DM patients with co-existing NAFLD also have an increased risk of PAD (peripheral artery disease) defined in this study as ABI (ankle-brachial index) < 0.90 on either side [149].

While an association between NAFLD and T2DM microvascular complications seems plausible, the number of studies on this topic is limited and inconclusive [144,150-154]. In 2008, Targher et al. performed one of the first studies evaluating the associations between 
NAFLD and both chronic kidney disease (CKD) and retinopathy in a large cohort of 2103 patients with T2DM and found that NAFLD was independently associated with an increased prevalence of CKD and retinopathy [151]. In the Valpolicella Heart Diabetes Study, among 1760 outpatients with T2DM who had normal kidney function at baseline, those with NAFLD had an independently increased risk of incident CKD over a follow-up period of 6.5 years [155]. These initial observations have been confirmed in further clinical studies and meta-analysis of observational studies [152,153], and moreover, it was shown that NAFLD increases the risk of diabetic neuropathy [156]. However, there are also studies that do not show such a relationship $[144,150,154]$. Results of the relevant studies are included in Table 6 .

It is well established that patients with DM compared to people without carbohydrate disorders have a higher risk of heart failure and CVD. There is a term "diabetic cardiomyopathy", deteriorating patient's prognosis and being described as a form of heart disease occurring in diabetic patients, which causes significant structural as well as functional changes in the myocardium. There is a common pathophysiological mechanism of diabetic cardiomyopathy and NAFLD, namely insulin resistance [157]. It results in an increase in lipogenesis in the liver and adipose tissue's lipolysis inhibition [89]. Insulin resistance also causes a decrease in the concentration of an insulin-sensitizing adipokine called adiponectin. Physiologically, adiponectin plays an important role in hepatoprotection by modifying free fatty acids metabolism, gluconeogenesis, and lipogenesis. Moreover, by reducing the number of proinflammatory cytokines and promoting the proliferation of hepatic stellate cells, it prevents liver fibrosis. In NAFLD, there are a couple of mechanisms (including dysfunction in adipokine production, increase in oxidative stress reactions, and general proinflammatory state) that influence the atherosclerotic plaque formation and its progression, therefore, leading to the increase of cardiovascular risk [158].

Table 6. NAFLD and cardiovascular disease.

\begin{tabular}{|c|c|c|c|c|c|}
\hline $\begin{array}{l}\text { Authors } \\
\text { (Year) }\end{array}$ & Study Type & $\begin{array}{l}\text { Studies/ } \\
\text { Participants } \\
\text { (N) }\end{array}$ & $\begin{array}{l}\text { Average } \\
\text { Duration of } \\
\text { Follow-Up }\end{array}$ & Population & Findings \\
\hline $\begin{array}{l}\text { Targher et al. } \\
(2008)[151]\end{array}$ & Cross-sectional & $1 / 2103$ & - & $\begin{array}{l}\text { T2DM patients with or } \\
\text { without CKD }\end{array}$ & $\begin{array}{l}\text { NAFLD was associated with increased rates of CKD } \\
\text { and proliferative/laser-treated retinopathy. }\end{array}$ \\
\hline $\begin{array}{l}\text { Agarwal } \\
\text { et al. (2011) } \\
\text { [145] }\end{array}$ & Retrospective & $1 / 124$ & - & $\begin{array}{l}\text { T2DM adults with or } \\
\text { without NAFLD }\end{array}$ & $\begin{array}{l}\text { The prevalence of NAFLD in T2DM patients was } 57.2 \% \text {. } \\
\text { In T2DM patients with NAFLD, CAD was more } \\
\text { prevalent compared to T2DM patients without NAFLD. }\end{array}$ \\
\hline $\begin{array}{l}\text { Stepanowa } \\
\text { et al. (2012) } \\
\text { [139] }\end{array}$ & Prospective & $1 / 11,613$ & 14 years & $\begin{array}{l}\text { Adults with or without } \\
\text { NAFLD }\end{array}$ & $\begin{array}{l}\text { NAFLD was associated with a higher risk of CVD. } \\
\text { NAFLD was not significantly associated with higher } \\
\text { CVD mortality. }\end{array}$ \\
\hline $\begin{array}{l}\text { Idilman et al. } \\
(2014)[146]\end{array}$ & Observational & $1 / 273$ & - & $\begin{array}{l}\text { T2DM adults without } \\
\text { previous known liver } \\
\text { disease }\end{array}$ & $\begin{array}{l}\text { In T2DM patients, NAFLD was associated with } \\
\text { significant CAD ( } \geq 50 \text { stenosis in CTA). }\end{array}$ \\
\hline $\begin{array}{l}\text { Kim et al. } \\
\text { (2014) [148] }\end{array}$ & Observational & $1 / 4437$ & - & $\begin{array}{l}\text { T2DM patients with or } \\
\text { without NAFLD }\end{array}$ & $\begin{array}{l}\text { The prevalence of NAFLD in T2DM patients was } 72.7 \% \text {. } \\
\text { Carotid IMT was significantly higher in T2DM patients } \\
\text { with NAFLD and insulin resistance compared to } \\
\text { insulin-sensitive T2DM patients without NAFLD and } \\
\text { insulin-sensitive T2DM patients with NAFLD. }\end{array}$ \\
\hline $\begin{array}{l}\text { Li et al. } \\
\text { (2014) [152] }\end{array}$ & Cross-sectional & $1 / 190$ & - & $\begin{array}{l}\text { Adults with diabetes and } \\
\text { prediabetes with or } \\
\text { without NAFLD }\end{array}$ & $\begin{array}{l}\text { Patients with NAFLD had a higher albumin-to-creatinine } \\
\text { ratio. CKD had a higher prevalence in T2DM patients } \\
\text { with NAFLD. }\end{array}$ \\
\hline $\begin{array}{l}\text { Musso } \\
\text { et al.(2014) } \\
{[153]}\end{array}$ & $\begin{array}{l}\text { Meta-analysis of } \\
\text { cross-sectional, } \\
\text { longitudinal studies }\end{array}$ & $20 / 29,282$ & - & $\begin{array}{l}\text { T2DM patients with or } \\
\text { without NAFLD }\end{array}$ & $\begin{array}{l}\text { NAFLD was associated with an increased risk of } \\
\text { prevalent and incident CKD. } \\
\text { NASH was associated with a higher prevalence and } \\
\text { incidence of CKD than simple steatosis. } \\
\text { Advanced fibrosis was associated with a higher } \\
\text { prevalence and incidence of CKD than non-advanced } \\
\text { fibrosis. }\end{array}$ \\
\hline $\begin{array}{l}\text { Mellinger } \\
\text { et al. (2015) } \\
{[131]}\end{array}$ & Prospective cohort & $1 / 3014$ & 3 years & $\begin{array}{l}\text { Adults with or without } \\
\text { NAFLD }\end{array}$ & $\begin{array}{l}\text { There was no significant association between NAFLD } \\
\text { and CVD. NAFLD was associated with CAC and AAC. }\end{array}$ \\
\hline $\begin{array}{l}\text { Lin et al. } \\
(2016)[154]\end{array}$ & Cross-sectional & $1 / 5963$ & - & $\begin{array}{l}\text { Adults with NAFLD with } \\
\text { or without T2DM }\end{array}$ & $\begin{array}{l}\text { NAFLD was not significantly associated with } \\
\text { retinopathy in T2DM patients. }\end{array}$ \\
\hline
\end{tabular}


Table 6. Cont.

\begin{tabular}{|c|c|c|c|c|c|}
\hline $\begin{array}{l}\text { Authors } \\
\text { (Year) }\end{array}$ & Study Type & $\begin{array}{l}\text { Studies/ } \\
\text { Participants } \\
\text { (N) }\end{array}$ & $\begin{array}{l}\text { Average } \\
\text { Duration of } \\
\text { Follow-Up }\end{array}$ & Population & Findings \\
\hline $\begin{array}{l}\text { Targher et al. } \\
\text { (2016) [159] }\end{array}$ & $\begin{array}{l}\text { Meta-analysis of } \\
\text { prospective, } \\
\text { retrospective, and } \\
\text { observational studies }\end{array}$ & $16 / 34,043$ & $\begin{array}{l}\text { median } \\
\text { period } \\
6.9 \text { years }\end{array}$ & $\begin{array}{l}\text { Adults with or without } \\
\text { NAFLD }\end{array}$ & $\begin{array}{l}\text { Patients with NAFLD had a higher risk of MACE than } \\
\text { patients without NAFLD. }\end{array}$ \\
\hline $\begin{array}{l}\text { Unalp- } \\
\text { Arida et al. } \\
\text { (2016) [140] }\end{array}$ & Retrospective cohort & $1 / 12,216$ & 6 years & $\begin{array}{l}\text { Adults with or without } \\
\text { NAFLD }\end{array}$ & $\begin{array}{l}\text { NAFLD was not independently associated with } \\
\text { mortality from all causes, including CVD, cancer, or } \\
\text { diabetes. }\end{array}$ \\
\hline $\begin{array}{l}\text { Wu et al. } \\
(2016)[138]\end{array}$ & $\begin{array}{l}\text { Meta-analysis, } \\
\text { systematic review of } \\
\text { cross-sectional and } \\
\text { cohort studies }\end{array}$ & $34 / 164,494$ & $\begin{array}{c}1.6- \\
26.4 \text { years }\end{array}$ & $\begin{array}{l}\text { Adults with or without } \\
\text { NAFLD }\end{array}$ & $\begin{array}{c}\text { NAFLD was associated with increased risk of prevalent } \\
\text { and incident CVD, prevalent atherosclerosis, prevalent } \\
\text { and incident hypertension, prevalent and incident CAD. } \\
\text { NAFLD was not associated with overall and CVD } \\
\text { mortality. }\end{array}$ \\
\hline $\begin{array}{l}\text { Yan et al. } \\
(2016)[144]\end{array}$ & $\begin{array}{l}\text { Observational, } \\
\text { retrospective }\end{array}$ & $1 / 212$ & - & $\begin{array}{l}\text { T2DM patients with or } \\
\text { without NAFLD }\end{array}$ & $\begin{array}{c}\text { Patients with NAFLD diagnosed earlier than T2DM had } \\
\text { a significantly higher prevalence of CAD and } \\
\text { hypertension and lower prevalence of diabetic } \\
\text { retinopathy and diabetic peripheral neuropathy } \\
\text { compared to T2DM patients with NAFLD diagnosed } \\
\text { later than T2DM and T2DM patients without NAFLD. } \\
\text { There was no significant difference in the prevalence of } \\
\text { diabetic kidney disease. }\end{array}$ \\
\hline $\begin{array}{l}\text { Zou et al. } \\
(2016)[149]\end{array}$ & Cross-sectional & $1 / 2646$ & - & $\begin{array}{l}\text { T2DM patients } \geq 40 \text { years } \\
\text { old with or without } \\
\text { NAFLD }\end{array}$ & $\begin{array}{c}\text { T2DM patients with NAFLD had a significantly higher } \\
\text { prevalence of PAD compared with those without } \\
\text { NAFLD. The prevalence of NAFLD among T2DM } \\
\text { patients was } 10.3 \% \text {. } \\
\text { NAFLD was associated with an increased risk of PAD. }\end{array}$ \\
\hline $\begin{array}{l}\text { Guo et al. } \\
\text { (2017) [147] }\end{array}$ & Cross-sectional & $1 / 8571$ & - & $\begin{array}{l}\text { T2DM patients with or } \\
\text { without NAFLD }\end{array}$ & $\begin{array}{c}\text { The prevalence of carotid and lower limb plaque, as well } \\
\text { as carotid and lower limb stenosis, was significantly } \\
\text { higher in T2DM patients with NAFLD than in T2DM } \\
\text { patients without NAFLD. } \\
\text { There was no significant difference between T2DM } \\
\text { patients with or without NAFLD in carotid IMT. }\end{array}$ \\
\hline $\begin{array}{l}\text { Yoshitaka } \\
\text { et al. (2017) } \\
\text { [136] }\end{array}$ & Cohort & $1 / 1674$ & 6 years & $\begin{array}{l}\text { Overweight and } \\
\text { non-overweight patients } \\
\text { with or without NAFLD }\end{array}$ & $\begin{array}{l}\text { NAFLD was associated with a higher risk of CVD } \\
\text { incidents in non-overweight patients with NAFLD. }\end{array}$ \\
\hline $\begin{array}{l}\text { Kapuria } \\
\text { et al. }(2018) \\
{[129]}\end{array}$ & $\begin{array}{l}\text { Meta-analysis, } \\
\text { systematic review of } \\
\text { cross-sectional and } \\
\text { cohort studies }\end{array}$ & $12 / 42,410$ & - & $\begin{array}{l}\text { Adults with or without } \\
\text { NAFLD }\end{array}$ & $\begin{array}{l}\text { NAFLD was associated with a higher CAC score } \\
\text { compared to adults without NAFLD. }\end{array}$ \\
\hline $\begin{array}{l}\text { Zhou et al. } \\
\text { (2018) [130] }\end{array}$ & $\begin{array}{l}\text { Meta-analysis, } \\
\text { systematic review of } \\
\text { cross-sectional, } \\
\text { case-control, and cohort } \\
\text { studies }\end{array}$ & $26 / 83,395$ & - & $\begin{array}{l}\text { Adults with or without } \\
\text { NAFLD }\end{array}$ & $\begin{array}{l}\text { NAFLD was associated with a higher risk of increased } \\
\text { carotid IMT, arterial stiffness, coronary artery } \\
\text { calcification, and endothelial disfunction. }\end{array}$ \\
\hline $\begin{array}{l}\text { Zhou et al. } \\
(2018)[143]\end{array}$ & $\begin{array}{l}\text { Meta-analysis of } \\
\text { cross-sectional, cohort } \\
\text { studies }\end{array}$ & $11 / 8346$ & $\begin{array}{l}\text { At least } \\
5 \text { years }\end{array}$ & $\begin{array}{l}\text { T1DM and T2DM adults } \\
\text { with or without NAFLD }\end{array}$ & $\begin{array}{l}\text { T2DM patients with diagnosed NAFLD had a } 2 \text { times } \\
\text { higher risk for CVD compared with patients without } \\
\text { NAFLD. }\end{array}$ \\
\hline $\begin{array}{l}\text { Afarideh } \\
\text { et al. (2019) } \\
\text { [150] }\end{array}$ & Case-control & $1 / 935$ & - & $\begin{array}{l}\text { T2DM patients with at } \\
\text { least one microvascular } \\
\text { complication vs. T2DM } \\
\text { patients control group }\end{array}$ & $\begin{array}{c}\text { Diabetic retinopathy and DKD were inversely associated } \\
\text { with the presence of NAFLD. } \\
\text { The subgroup of NAFLD with elevated liver enzymes } \\
\text { had lower odds of having diabetic peripheral } \\
\text { neuropathy. }\end{array}$ \\
\hline $\begin{array}{l}\text { Alexander } \\
\text { et al. }(2019) \\
{[141]}\end{array}$ & Cohort & $1 / 120,795$ & $\begin{array}{c}\text { mean } \\
2.1-5.5 \text { years }\end{array}$ & Adults with NAFLD & $\begin{array}{c}\text { After adjustment for established cardiovascular risk } \\
\text { factors, NAFLD was not associated with AMI or stroke } \\
\text { risk. }\end{array}$ \\
\hline $\begin{array}{l}\text { Lee et al. } \\
(2020)[160]\end{array}$ & Cohort & $1 / 1120$ & $6-8$ years & $\begin{array}{l}\text { T2DM patients with or } \\
\text { without NAFLD }\end{array}$ & $\begin{array}{l}\text { NAFLD was significantly associated with atherosclerosis } \\
\text { progression. }\end{array}$ \\
\hline $\begin{array}{l}\text { Mann et al. } \\
(2020) \text { [137] }\end{array}$ & Retrospective cohort & $1 / 26,539$ & $\begin{array}{l}14 \text { years } \\
\text { after } \\
\text { discharge }\end{array}$ & $\begin{array}{l}\text { Patients with or without } \\
\text { NAFLD }\end{array}$ & $\begin{array}{l}\text { Patients with NAFLD without cirrhosis and NAFLD } \\
\text { with cirrhosis } \\
\text { had higher mortality compared to controls. }\end{array}$ \\
\hline $\begin{array}{l}\text { Shao et al. } \\
(2020) \text { [135] }\end{array}$ & Cross-sectional & $1 / 543$ & - & $\begin{array}{l}\text { Obese patients with } \\
\text { NAFLD vs. non-obese } \\
\text { patients with NAFLD }\end{array}$ & $\begin{array}{l}\text { Predictive factors of subclinical atherosclerosis in all } \\
\text { patients with NAFLD were age increased per } 10 \text { years } \\
\text { and liver stiffness. LFC was an additional predictor in } \\
\text { obese patients with NAFLD. }\end{array}$ \\
\hline $\begin{array}{l}\text { Greco et al. } \\
(2021)[161]\end{array}$ & $\begin{array}{c}\text { Meta-analysis, } \\
\text { systematic review of } \\
\text { cross-sectional studies }\end{array}$ & $13 / 9614$ & - & $\begin{array}{l}\text { T1DM and T2DM patients } \\
\text { with or without NAFLD }\end{array}$ & $\begin{array}{l}\text { Diabetic peripheral neuropathy prevalence was } \\
\text { significantly higher in T2DM patients with NAFLD } \\
\text { compared to T2DM patients without NAFLD, but not in } \\
\text { T1DM patients with NAFLD. }\end{array}$ \\
\hline
\end{tabular}


Table 6. Cont.

\begin{tabular}{|c|c|c|c|c|c|}
\hline $\begin{array}{l}\text { Authors } \\
\text { (Year) }\end{array}$ & Study Type & $\begin{array}{c}\text { Studies/ } \\
\text { Participants } \\
\text { (N) }\end{array}$ & $\begin{array}{c}\text { Average } \\
\text { Duration of } \\
\text { Follow-Up }\end{array}$ & Population & Findings \\
\hline $\begin{array}{l}\text { Meyersohn } \\
\text { et al. (2021) } \\
\text { [133] }\end{array}$ & Cohort & $1 / 3756$ & 25 months & $\begin{array}{l}\text { Symptomatic patients } \\
\text { without previous } \\
\text { diagnosed CAD }\end{array}$ & $\begin{array}{l}\text { NAFLD was associated with MACE independently of } \\
\text { other cardiovascular risk factors or extent of CAD. }\end{array}$ \\
\hline $\begin{array}{l}\text { Lee et al. } \\
(2021)[142]\end{array}$ & Cohort & $1 / 8,962,813$ & $\begin{array}{c}\text { median } \\
10.1 \text { years }\end{array}$ & $\begin{array}{l}\text { Adults with or without } \\
\text { NAFLD }\end{array}$ & $\begin{array}{l}\text { NAFLD and MAFLD were associated with significantly } \\
\text { higher risk for CVD events. }\end{array}$ \\
\hline & & \multicolumn{4}{|c|}{$\begin{array}{l}\text { Abbreviations: AAC—abdominal artery calcium, AMI-acute myocardial infarction, AOR-adjusted odds } \\
\text { ratio, CAC-coronary artery calcium, CAD—coronary artery disease, CI-credible interval, CKD-chronic } \\
\text { kidney disease, CTA-computed tomography angiography, CVD-cardiovascular disease, HR-hazard ratio } \\
\text { DKD-diabetic kidney disease, IMT-intima-media thickness, LFC-liver fat content, MACE-major adverse } \\
\text { cardiovascular events, MAFLD—-metabolic associated fatty liver disease, NAFLD—-non-alcoholic fatty liver } \\
\text { disease, OR-odds ratio, PAD—peripheral artery disease, T1DM-type } 1 \text { diabetes mellitus, T2DM-type } 2 \\
\text { diabetes mellitus. }\end{array}$} \\
\hline
\end{tabular}

\section{Conclusions}

MAFLD is a new clinical definition for fatty liver disease, which shifts NAFLD from a disease of exclusion to one of inclusion, where the pathogenic processes originate from underlying metabolic dysfunction. Because MAFLD is not widely used terminology in the scientific literature, most published data focus on NAFLD. The latter as an epidemic is tightly linked to T2DM, which are known to frequently coexist with and synergistically increase the CVD risk.

Despite the high prevalence of NAFLD and many epidemiological studies showing correlations between NAFLD and CVD, it is still difficult to unequivocally identify a causal relationship between the two entities [162] and to show that NAFLD is an independent risk factor for CVD [163], given the presence of many comorbidities and confounding factors. In addition, the available studies show great heterogeneity. Also, the genetic variants that predispose to the development of NAFLD have not been linked to the development of atherosclerotic CVD in the absence of general obesity and metabolic syndrome [164].

We are still unclear whether the diagnosis of NAFLD can be used as a tool to improve cardiovascular risk and modify treatment [162]. Lifestyle interventions are recommended by the European clinical guidelines as the best therapeutic option for human NAFLD [9,165]. Moreover, $\geq 7 \%$ weight loss improves steatosis significantly, resulting in lowering of the NAFLD activity score (NAS) [166,167]. On the other hand, only $40 \%$ of patients in the above study reached that goal and reduced steatohepatitis, underlining the difficulties in managing NAFLD with lifestyle changes [166]. Nevertheless, reduction of fructose should be recommended for patients with NAFLD along with emerging therapies that can lower the activity of liver enzymes, fibrosis, and inflammation, such as PPAR $\gamma$ inhibitors (pioglitazone), SGLT-2i, and GLP-1 RA, as well as modification in gut microbiota.

Author Contributions: Conceptualization: K.D., K.N., J.G. and G.Y.H.L.; writing-original draft preparation: K.D., K.N., W.H., H.K., J.G. and G.Y.H.L.; writing-review and editing: K.D., K.N., W.H., H.K., J.G. and G.Y.H.L.; visualization: K.D., K.N. All authors have read and agreed to the published version of the manuscript.

Funding: This research received no external funding.

Institutional Review Board Statement: Not applicable.

Informed Consent Statement: Not applicable.

Data Availability Statement: No new data were created or analyzed in this study. Data sharing is not applicable to this article.

Conflicts of Interest: The authors declare no conflict of interest directly related to this paper. 


\section{References}

1. Schaffner, F.; Thaler, H. Nonalcoholic fatty liver disease. Prog. Liver Dis. 1986, 8, 83-298.

2. Lonardo, A.; Bellini, M.; Tondelli, E.; Frazzoni, M.; Grisendi, A.; Pulvirenti, M.; Della Casa, G. Nonalcoholic steatohepatitis and the "bright liver syndrome": Should a recently expanded clinical entity be further expanded? Am. J. Gastroenterol. 1995, 90, 2072-2074. [PubMed]

3. Farrell, G.C.; Chitturi, S.; Lau, G.K.K.; Sollano, J.D. Guidelines for the assessment and management of non-alcoholic fatty liver disease in the Asia-Pacific region: Executive summary. J. Gastroenterol. Hepatol. 2007, 22, 775-777. [CrossRef] [PubMed]

4. Chalasani, N.; Younossi, Z.M.; LaVine, J.E.; Diehl, A.M.; Brunt, E.M.; Cusi, K.; Charlton, M.; Sanyal, A.J. The diagnosis and management of non-alcoholic fatty liver disease: Practice Guideline by the American Association for the Study of Liver Diseases, American College of Gastroenterology, and the American Gastroenterological Association. Hepatology 2012, 55, $2005-2023$. [CrossRef]

5. Ratziu, V.; Bellentani, S.; Cortez-Pinto, H.; Day, C.; Marchesini, G. A position statement on NAFLD/NASH based on the EASL 2009 special conference. J. Hepatol. 2010, 53, 372-384. [CrossRef] [PubMed]

6. Addison, T. Observations on fatty degeneration of the liver. Guys Hosp Rep. 1836, 1, 485.

7. Pepper, W.; Starr, L. A System of Practical Medicine by American Authors. Am. J. Med Sci. 1885, 180, 550-562. [CrossRef]

8. Ludwig, J.; Viggiano, T.R.; McGill, D.B.; Oh, B.J. Nonalcoholic steatohepatitis: Mayo Clinic experiences with a hitherto unnamed disease. Mayo Clin. Proc. 1980, 55, 434-438. [PubMed]

9. European Association for the Study of the Liver (EASL); European Association for the Study of Diabetes (EASD); European Association for the Study of Obesity (EASO). EASL-EASD-EASO Clinical Practice Guidelines for the management of nonalcoholic fatty liver disease. J. Hepatol. 2016, 64, 1388-1402. [CrossRef] [PubMed]

10. Eslam, M.; Newsome, P.N.; Sarin, S.K.; Anstee, Q.M.; Targher, G.; Romero-Gomez, M.; Zelber-Sagi, S.; Wong, V.W.-S.; Dufour, J.-F.; Schattenberg, J.M.; et al. A new definition for metabolic dysfunction-associated fatty liver disease: An international expert consensus statement. J. Hepatol. 2020, 73, 202-209. [CrossRef] [PubMed]

11. Rinaldi, L.; Pafundi, P.C.; Galiero, R.; Caturano, A.; Morone, M.V.; Silvestri, C.F.; Giordano, M.; Salvatore, T.; Sasso, F.C. Mechanisms of Non-Alcoholic Fatty Liver Disease in the Metabolic Syndrome. A Narrative Review. Antioxidants 2021, 10, 270. [CrossRef] [PubMed]

12. Fouad, Y.; Waked, I.; Bollipo, S.; Gomaa, A.; Ajlouni, Y.; Attia, D. What's in a name? Renaming 'NAFLD' to 'MAFLD'. Liver Int. 2020, 40, 1254-1261. [CrossRef]

13. Wong, R.J.; Cheung, R.; Ahmed, A. Nonalcoholic steatohepatitis is the most rapidly growing indication for liver transplantation in patients with hepatocellular carcinoma in the U.S. Hepatology 2014, 59, 2188-2195. [CrossRef] [PubMed]

14. Younossi, Z.M.; Golabi, P.; de Avila, L.; Paik, J.M.; Srishord, M.; Fukui, N.; Qiu, Y.; Burns, L.; Afendy, A.; Nader, F. The global epidemiology of NAFLD and NASH in patients with type 2 diabetes: A systematic review and meta-analysis. J. Hepatol. 2019, 71, 793-801. [CrossRef] [PubMed]

15. Noureddin, M.; Vipani, A.; Bresee, C.; Todo, T.; Kim, I.K.; Alkhouri, N.; Setiawan, V.; Tran, T.; Ayoub, W.S.; Lu, S.C.; et al. NASH Leading Cause of Liver Transplant in Women: Updated Analysis of Indications for Liver Transplant and Ethnic and Gender Variances. Am. J. Gastroenterol. 2018, 113, 1649-1659. [CrossRef]

16. Cave, M.; Deaciuc, I.; Mendez, C.; Song, Z.; Joshi-Barve, S.; Barve, S.; McClain, C. Nonalcoholic fatty liver disease: Predisposing factors and the role of nutrition. J. Nutr. Biochem. 2007, 18, 184-195. [CrossRef] [PubMed]

17. Elliott, S.S.; Keim, N.L.; Stern, J.S.; Teff, K.; Havel, P.J. Fructose, weight gain, and the insulin resistance syndrome. Am. J. Clin. Nutr. 2002, 76, 911-922. [CrossRef]

18. Jensen, T.; Abdelmalek, M.F.; Sullivan, S.; Nadeau, K.J.; Cree-Green, M.; Roncal, C.; Nakagawa, T.; Kuwabara, M.; Sato, Y.; Kang, D.-H.; et al. Fructose and sugar: A major mediator of non-alcoholic fatty liver disease. J. Hepatol. 2018, 68, 1063-1075. [CrossRef] [PubMed]

19. Basaranoglu, M.; Basaranoglu, G.; Bugianesi, E. Carbohydrate intake and nonalcoholic fatty liver disease: Fructose as a weapon of mass destruction. Hepatobiliary Surg. Nutr. 2015, 4, 109-116. [CrossRef]

20. Sánchez-Lozada, L.G.; Mu, W.; Roncal, C.; Sautin, Y.Y.; Abdelmalek, M.; Reungjui, S.; Le, M.; Nakagawa, T.; Lan, H.Y.; Yu, X.; et al. Comparison of free fructose and glucose to sucrose in the ability to cause fatty liver. Eur. J. Nutr. 2009, 49, 1-9. [CrossRef] [PubMed]

21. Aron-Wisnewsky, J.; Vigliotti, C.; Witjes, J.; Le, P.; Holleboom, A.G.; Verheij, J.; Nieuwdorp, M.; Clément, K. Gut microbiota and human NAFLD: Disentangling microbial signatures from metabolic disorders. Nat. Rev. Gastroenterol. Hepatol. 2020, 17, $279-297$. [CrossRef]

22. Wong, R.J.; Aguilar, M.; Cheung, R.; Perumpail, R.B.; Harrison, S.A.; Younossi, Z.M.; Ahmed, A. Nonalcoholic Steatohepatitis Is the Second Leading Etiology of Liver Disease among Adults Awaiting Liver Transplantation in the United States. Gastroenterology 2015, 148, 547-555. [CrossRef] [PubMed]

23. Haldar, D.; Kern, B.; Hodson, J.; Armstrong, M.; Adam, R.; Berlakovich, G.; Fritz, J.; Feurstein, B.; Popp, W.; Karam, V.; et al. Outcomes of liver transplantation for non-alcoholic steatohepatitis: A European Liver Transplant Registry study. J. Hepatol. 2019, 71, 313-322. [CrossRef] [PubMed]

24. Targher, G.; Byrne, C.D.; Tilg, H. NAFLD and increased risk of cardiovascular disease: Clinical associations, pathophysiological mechanisms and pharmacological implications. Gut 2020, 69, 1691-1705. [CrossRef] [PubMed] 
25. Koivisto, V.A. Fructose as a Dietary Sweetener in Diabetes Mellitus. Diabetes Care 1978, 1, 241-246. [CrossRef]

26. Moorhouse, J.A.; Kark, R.M. Fructose and diabetes. Am. J. Med. 1957, 23, 46-58. [CrossRef]

27. Pelkonen, R.; Aro, A.; Nikkilä, E.A. Metabolic Effects of Dietary Fructose in Insulin Dependent Diabetes of Adults. Acta Med. Scand. 2009, 192, 187-193. [CrossRef]

28. Lim, J.S.; Mietus-Snyder, M.; Valente, A.; Schwarz, J.-M.; Lustig, R.H. The role of fructose in the pathogenesis of NAFLD and the metabolic syndrome. Nat. Rev. Gastroenterol. Hepatol. 2010, 7, 251-264. [CrossRef]

29. Schwarz, J.-M.; Noworolski, S.M.; Wen, M.J.; Dyachenko, A.; Prior, J.L.; Weinberg, M.E.; Herraiz, L.A.; Tai, V.W.; Bergeron, N.; Bersot, T.P.; et al. Effect of a High-Fructose Weight-Maintaining Diet on Lipogenesis and Liver Fat. J. Clin. Endocrinol. Metab. 2015, 100, 2434-2442. [CrossRef] [PubMed]

30. Stanhope, K.L.; Schwarz, J.M.; Keim, N.L.; Griffen, S.C.; Bremer, A.A.; Graham, J.L.; Hatcher, B.; Cox, C.L.; Dyachenko, A.; Zhang, W.; et al. Consuming fructose-sweetened, not glucose-sweetened, beverages increases visceral adiposity and lipids and decreases insulin sensitivity in overweight/obese humans. J. Clin. Investig. 2009, 119, 1322-1334. [CrossRef] [PubMed]

31. Skenderian, S.; Park, G.; Jang, C. Organismal Fructose Metabolism in Health and Non-Alcoholic Fatty Liver Disease. Biology 2020, 9, 405. [CrossRef] [PubMed]

32. Jegatheesan, P.; De Bandt, J. Fructose and NAFLD: The Multifaceted Aspects of Fructose Metabolism. Nutrients 2017, 9, 230. [CrossRef] [PubMed]

33. Johnson, R.J.; Sanchez-Lozada, L.-G.; Andrews, P.; Lanaspa, M.A. Perspective: A Historical and Scientific Perspective of Sugar and Its Relation with Obesity and Diabetes. Adv. Nutr. 2017, 8, 412-422. [CrossRef]

34. GBD 2016 Risk Factors Collaborators. Global, regional, and national comparative risk assessment of 84 behavioural, environmental and occupational, and metabolic risks or clusters of risks, 1990-2016: A systematic analysis for the Global Burden of Disease Study 2016. Lancet 2017, 390, 1345-1422. [CrossRef]

35. World Health Organization (WHO). Guidelines on Sugar Intake. Available online: https://www.who.int/elena/titles/guidance summaries/sugars_intake/en/ (accessed on 24 November 2021).

36. Zelber-Sagi, S.; Nitzan-Kaluski, D.; Goldsmith, R.; Webb, M.; Blendis, L.; Halpern, Z.; Oren, R. Long term nutritional intake and the risk for non-alcoholic fatty liver disease (NAFLD): A population based study. J. Hepatol. 2007, 47, 711-717. [CrossRef] [PubMed]

37. Assy, N.; Nasser, G.; Kamayse, I.; Nseir, W.; Beniashvili, Z.; Djibre, A.; Grosovski, M. Soft Drink Consumption Linked with Fatty Liver in the Absence of Traditional Risk Factors. Can. J. Gastroenterol. 2008, 22, 811-816. [CrossRef] [PubMed]

38. Abid, A.; Taha, O.; Nseir, W.; Farah, R.; Grosovski, M.; Assy, N. Soft drink consumption is associated with fatty liver disease independent of metabolic syndrome. J. Hepatol. 2009, 51, 918-924. [CrossRef] [PubMed]

39. Abdelmalek, M.F.; Suzuki, A.; Guy, C.; Unalp-Arida, A.; Colvin, R.; Johnson, R.J.; Diehl, A.M.; Nonalcoholic Steatohepatitis Clinical Research Network. Increased fructose consumption is associated with fibrosis severity in patients with nonalcoholic fatty liver disease. Hepatology 2010, 51, 1961-1971. [CrossRef] [PubMed]

40. Maersk, M.; Belza, A.; Stødkilde-Jørgensen, H.; Ringgaard, S.; Chabanova, E.; Thomsen, H.; Pedersen, S.B.; Astrup, A.; Richelsen, B. Sucrose-sweetened beverages increase fat storage in the liver, muscle, and visceral fat depot: A 6-mo randomized intervention study. Am. J. Clin. Nutr. 2011, 95, 283-289. [CrossRef] [PubMed]

41. Chiu, S.; Sievenpiper, J.L.; de Souza, R.; Cozma, A.I.; Mirrahimi, A.; Carleton, A.J.; Ha, V.; Di Buono, M.; Jenkins, A.L.; Leiter, L.A.; et al. Effect of fructose on markers of non-alcoholic fatty liver disease (NAFLD): A systematic review and meta-analysis of controlled feeding trials. Eur. J. Clin. Nutr. 2014, 68, 416-423. [CrossRef]

42. Chung, M.; Ma, J.; Patel, K.; Berger, S.; Lau, J.; Lichtenstein, A.H. Fructose, high-fructose corn syrup, sucrose, and nonalcoholic fatty liver disease or indexes of liver health: A systematic review and meta-analysis. Am. J. Clin. Nutr. 2014, 100, 833-849. [CrossRef]

43. Hochuli, M.; Herter-Aeberli, I.; Weiss, A.; Hersberger, M.; Troxler, H.; Gerber, P.; Spinas, G.A.; Berneis, K. Sugar-Sweetened Beverages with Moderate Amounts of Fructose, but Not Sucrose, Induce Fatty Acid Synthesis in Healthy Young Men: A Randomized Crossover Study. J. Clin. Endocrinol. Metab. 2014, 99, 2164-2172. [CrossRef] [PubMed]

44. Jin, R.; Welsh, J.A.; Le, N.-A.; Holzberg, J.; Sharma, P.; Martin, D.R.; Vos, M.B. Dietary Fructose Reduction Improves Markers of Cardiovascular Disease Risk in Hispanic-American Adolescents with NAFLD. Nutrients 2014, 6, 3187-3201. [CrossRef] [PubMed]

45. Ma, J.; Fox, C.S.; Jacques, P.F.; Speliotes, E.K.; Hoffmann, U.; Smith, C.E.; Saltzman, E.; McKeown, N.M. Sugar-sweetened beverage, diet soda, and fatty liver disease in the Framingham Heart Study cohorts. J. Hepatol. 2015, 63, 462-469. [CrossRef] [PubMed]

46. Wijarnpreecha, K.; Thongprayoon, C.; Edmonds, P.; Cheungpasitporn, W. Associations of sugar- and artificially sweetened soda with nonalcoholic fatty liver disease: A systematic review and meta-analysis. QJM Int. J. Med. 2016, 109, 461-466. [CrossRef] [PubMed]

47. Chen, H.; Wang, J.; Li, Z.; Lam, C.W.K.; Xiao, Y.; Wu, Q.; Zhang, W. Consumption of Sugar-Sweetened Beverages Has a Dose-Dependent Effect on the Risk of Non-Alcoholic Fatty Liver Disease: An Updated Systematic Review and Dose-Response Meta-Analysis. Int. J. Environ. Res. Public Health 2019, 16, 2192. [CrossRef] [PubMed]

48. Lambertz, J.; Weiskirchen, S.; Landert, S.; Weiskirchen, R. Fructose: A Dietary Sugar in Crosstalk with Microbiota Contributing to the Development and Progression of Non-Alcoholic Liver Disease. Front. Immunol. 2017, 8, 1159. [CrossRef]

49. Ridaura, V.K.; Faith, J.J.; Rey, F.E.; Cheng, J.; Duncan, A.E.; Kau, A.L.; Griffin, N.W.; Lombard, V.; Henrissat, B.; Bain, J.R.; et al. Gut Microbiota from Twins Discordant for Obesity Modulate Metabolism in Mice. Science 2013, 341, 1241214. [CrossRef] [PubMed] 
50. Aron-Wisnewsky, J.; Gaborit, B.; Dutour, A.; Clement, K. Gut microbiota and non-alcoholic fatty liver disease: New insights. Clin. Microbiol. Infect. 2013, 19, 338-348. [CrossRef]

51. Wieland, A.; Frank, D.N.; Harnke, B.; Bambha, K. Systematic review: Microbial dysbiosis and nonalcoholic fatty liver disease. Aliment. Pharmacol. Ther. 2015, 42, 1051-1063. [CrossRef] [PubMed]

52. Roychowdhury, S.; Selvakumar, P.C.; Cresci, G.A. The Role of the Gut Microbiome in Nonalcoholic Fatty Liver Disease. Med. Sci. 2018, 6, 47. [CrossRef] [PubMed]

53. Henao-Mejia, J.; Elinav, E.; Jin, C.; Hao, L.; Mehal, W.Z.; Strowig, T.; Thaiss, C.A.; Kau, A.L.; Eisenbarth, S.C.; Jurczak, M.J.; et al. Inflammasome-mediated dysbiosis regulates progression of NAFLD and obesity. Nature 2012, 482, 179-185. [CrossRef] [PubMed]

54. Chiu, C.-C.; Ching, Y.-H.; Li, Y.-P.; Liu, J.-Y.; Huang, Y.-T.; Huang, Y.-W.; Yang, S.-S.; Huang, W.-C.; Chuang, H.-L. Nonalcoholic Fatty Liver Disease Is Exacerbated in High-Fat Diet-Fed Gnotobiotic Mice by Colonization with the Gut Microbiota from Patients with Nonalcoholic Steatohepatitis. Nutrients 2017, 9, 1220. [CrossRef] [PubMed]

55. Farrell, G.; Schattenberg, J.M.; Leclercq, I.; Yeh, M.M.; Goldin, R.; Teoh, N.; Schuppan, D. Mouse Models of Nonalcoholic Steatohepatitis: Toward Optimization of Their Relevance to Human Nonalcoholic Steatohepatitis. Hepatology $2018,69,2241-2257$. [CrossRef] [PubMed]

56. Nguyen, T.L.A.; Vieira-Silva, S.; Liston, A.; Raes, J. How informative is the mouse for human gut microbiota research? Dis. Model. Mech. 2015, 8, 1-16. [CrossRef]

57. Brandl, K.; Schnabl, B. Intestinal microbiota and nonalcoholic steatohepatitis. Curr. Opin. Gastroenterol. 2017, 33, 128-133. [CrossRef] [PubMed]

58. Albillos, A.; de Gottardi, A.; Rescigno, M. The gut-liver axis in liver disease: Pathophysiological basis for therapy. J. Hepatol. 2020, 72, 558-577. [CrossRef] [PubMed]

59. Hu, H.; Lin, A.; Kong, M.; Yao, X.; Yin, M.; Xia, H.; Ma, J.; Liu, H. Intestinal microbiome and NAFLD: Molecular insights and therapeutic perspectives. J. Gastroenterol. 2019, 55, 142-158. [CrossRef]

60. Dong, T.S.; Jacobs, J.P. Nonalcoholic fatty liver disease and the gut microbiome: Are bacteria responsible for fatty liver? Exp. Biol. Med. 2019, 244, 408-418. [CrossRef] [PubMed]

61. Wang, B.; Jiang, X.; Cao, M.; Ge, J.; Bao, Q.; Tang, L.; Chen, Y.; Li, L. Altered Fecal Microbiota Correlates with Liver Biochemistry in Nonobese Patients with Non-alcoholic Fatty Liver Disease. Sci. Rep. 2016, 6, 32002. [CrossRef]

62. Shen, F.; Zheng, R.-D.; Sun, X.-Q.; Ding, W.-J.; Wang, X.-Y.; Fan, J.-G. Gut microbiota dysbiosis in patients with non-alcoholic fatty liver disease. Hepatobiliary Pancreat. Dis. Int. 2017, 16, 375-381. [CrossRef]

63. Li, F.; Ye, J.; Shao, C.; Zhong, B. Compositional alterations of gut microbiota in nonalcoholic fatty liver disease patients: A systematic review and Meta-analysis. Lipids Health Dis. 2021, 20, 22. [CrossRef]

64. Lanthier, N.; Rodriguez, J.; Nachit, M.; Hiel, S.; Trefois, P.; Neyrinck, A.M.; Cani, P.D.; Bindels, L.B.; Thissen, J.-P.; Delzenne, N.M. Microbiota analysis and transient elastography reveal new extra-hepatic components of liver steatosis and fibrosis in obese patients. Sci. Rep. 2021, 11, 659. [CrossRef]

65. Raman, M.; Ahmed, I.; Gillevet, P.M.; Probert, C.S.; Ratcliffe, N.M.; Smith, S.; Greenwood, R.; Sikaroodi, M.; Lam, V.; Crotty, P.; et al. Fecal Microbiome and Volatile Organic Compound Metabolome in Obese Humans with Nonalcoholic Fatty Liver Disease. Clin. Gastroenterol. Hepatol. 2013, 11, 868-875.e3. [CrossRef]

66. Da Silva, H.E.; Teterina, A.; Comelli, E.M.; Taibi, A.; Arendt, B.M.; Fischer, S.E.; Lou, W.; Allard, J.P. Nonalcoholic fatty liver disease is associated with dysbiosis independent of body mass index and insulin resistance. Sci. Rep. 2018, 8, 1466. [CrossRef] [PubMed]

67. Arasaradnam, R.P.; Covington, J.; Harmston, C.; Nwokolo, C.U. Review article: Next generation diagnostic modalities in gastroenterology_Gas phase volatile compound biomarker detection. Aliment. Pharmacol. Ther. 2014, 39, 780-789. [CrossRef]

68. Ma, Y.Y.; Li, L.; Yu, C.H.; Shen, Z.; Chen, L.H.; Li, Y.M. Effects of probiotics on nonalcoholic fatty liver disease: A meta-analysis. World J. Gastroenterol. 2013, 19, 6911-6918. [CrossRef] [PubMed]

69. Loman, B.; Hernández-Saavedra, D.; An, R.; Rector, R.S. Prebiotic and probiotic treatment of nonalcoholic fatty liver disease: A systematic review and meta-analysis. Nutr. Rev. 2018, 76, 822-839. [CrossRef] [PubMed]

70. Khan, M.Y.; Mihali, A.B.; Rawala, M.S.; Aslam, A.; Siddiqui, W.J. The promising role of probiotic and synbiotic therapy in aminotransferase levels and inflammatory markers in patients with nonalcoholic fatty liver disease-A systematic review and meta-analysis. Eur. J. Gastroenterol. Hepatol. 2019, 31, 703-715. [CrossRef] [PubMed]

71. Sharpton, S.R.; Maraj, B.; Harding-Theobald, E.; Vittinghoff, E.; Terrault, N.A. Gut microbiome-targeted therapies in nonalcoholic fatty liver disease: A systematic review, meta-analysis, and meta-regression. Am. J. Clin. Nutr. 2019, 110, 139-149. [CrossRef] [PubMed]

72. Pan, X.; Wen, S.W.; Kaminga, A.C.; Liu, A. Gut metabolites and inflammation factors in non-alcoholic fatty liver disease: A systematic review and meta-analysis. Sci. Rep. 2020, 10, 8848. [CrossRef] [PubMed]

73. Binda, S.; Hill, C.; Johansen, E.; Obis, D.; Pot, B.; Sanders, M.E.; Tremblay, A.; Ouwehand, A.C. Criteria to Qualify Microorganisms as "Probiotic" in Foods and Dietary Supplements. Front. Microbiol. 2020, 11, 1662. [CrossRef] [PubMed]

74. Pineiro, M.; Asp, N.-G.; Reid, G.; Macfarlane, S.; Morelli, L.; Brunser, O.; Tuohy, K. FAO Technical Meeting on Prebiotics. J. Clin. Gastroenterol. 2008, 42, S156-S159. [CrossRef] [PubMed]

75. Markowiak, P.; Śliżewska, K. Effects of Probiotics, Prebiotics, and Synbiotics on Human Health. Nutrients 2017, 9, 1021. [CrossRef] 
76. Buzzetti, E.; Pinzani, M.; Tsochatzis, E.A. The multiple-hit pathogenesis of non-alcoholic fatty liver disease (NAFLD). Metabolism 2016, 65, 1038-1048. [CrossRef]

77. Bakhshimoghaddam, F.; Shateri, K.; Sina, M.; Hashemian, M.; Alizadeh, M. Daily Consumption of Synbiotic Yogurt Decreases Liver Steatosis in Patients with Nonalcoholic Fatty Liver Disease: A Randomized Controlled Clinical Trial. J. Nutr. 2018, 148, 1276-1284. [CrossRef] [PubMed]

78. Eslamparast, T.; Poustchi, H.; Zamani, F.; Sharafkhah, M.; Malekzadeh, R.; Hekmatdoost, A. Synbiotic supplementation in nonalcoholic fatty liver disease: A randomized, double-blind, placebo-controlled pilot study. Am. J. Clin. Nutr. 2014, 99, 535-542. [CrossRef]

79. Van Nood, E.; Vrieze, A.; Nieuwdorp, M.; Fuentes, S.; Zoetendal, E.G.; De Vos, W.M.; Visser, C.E.; Kuijper, E.J.; Bartelsman, J.F.W.M.; Tijssen, J.G.P.; et al. Duodenal Infusion of Donor Feces for Recurrent Clostridium difficile. N. Engl. J. Med. 2013, 368, 407-415. [CrossRef] [PubMed]

80. Aron-Wisnewsky, J.; Clément, K.; Nieuwdorp, M. Fecal Microbiota Transplantation: A Future Therapeutic Option for Obesity/Diabetes? Curr. Diabetes Rep. 2019, 19, 51. [CrossRef] [PubMed]

81. Craven, L.; Rahman, A.; Nair Parvathy, S.; Beaton, M.; Silverman, J.; Qumosani, K.; Hramiak, I.; Hegele, R.; Joy, T.; Meddings, J.; et al. Allogenic Fecal Microbiota Transplantation in Patients with Nonalcoholic Fatty Liver Disease Improves Abnormal Small Intestinal Permeability: A Randomized Control Trial. Am. J. Gastroenterol. 2020, 115, 1055-1065. [CrossRef] [PubMed]

82. Witjes, J.J.; Smits, L.P.; Pekmez, C.T.; Prodan, A.; Meijnikman, A.S.; Troelstra, M.A.; Bouter, K.E.; Herrema, H.; Levin, E.; Holleboom, A.G.; et al. Donor Fecal Microbiota Transplantation Alters Gut Microbiota and Metabolites in Obese Individuals with Steatohepatitis. Hepatol. Commun. 2020, 4, 1578-1590. [CrossRef]

83. Blond, E.; Disse, E.; Cuerq, C.; Drai, J.; Valette, P.-J.; Laville, M.; Thivolet, C.; Simon, C.; Caussy, C. EASL-EASD-EASO clinical practice guidelines for the management of non-alcoholic fatty liver disease in severely obese people: Do they lead to over-referral? Diabetologia 2017, 60, 1218-1222. [CrossRef] [PubMed]

84. Mantovani, A.; Byrne, C.D.; Bonora, E.; Targher, G. Nonalcoholic Fatty Liver Disease and Risk of Incident Type 2 Diabetes: A Meta-analysis. Diabetes Care 2018, 41, 372-382. [CrossRef]

85. Lallukka, S.; Yki-Järvinen, H. Non-alcoholic fatty liver disease and risk of type 2 diabetes. Best Pract. Res. Clin. Endocrinol. Metab. 2016, 30, 385-395. [CrossRef] [PubMed]

86. Lee, J.; Cho, Y.K.; Kang, Y.M.; Kim, H.S.; Jung, C.H.; Kim, H.-K.; Park, J.-Y.; Lee, W.J. The Impact of NAFLD and Waist Circumference Changes on Diabetes Development in Prediabetes Subjects. Sci. Rep. 2019, 9, 17258. [CrossRef]

87. Ballestri, S.; Zona, S.; Targher, G.; Romagnoli, D.; Baldelli, E.; Nascimbeni, F.; Roverato, A.; Guaraldi, G.; Lonardo, A. Nonalcoholic fatty liver disease is associated with an almost twofold increased risk of incident type 2 diabetes and metabolic syndrome. Evidence from a systematic review and meta-analysis. J. Gastroenterol. Hepatol. 2016, 31, 936-944. [CrossRef] [PubMed]

88. Kwok, R.; Choi, K.C.; Wong, G.L.-H.; Zhang, Y.; Chan, H.L.-Y.; Luk, A.O.-Y.; Shu, S.S.-T.; Chan, A.W.-H.; Yeung, M.-W.; Chan, J.C.-N.; et al. Screening diabetic patients for non-alcoholic fatty liver disease with controlled attenuation parameter and liver stiffness measurements: A prospective cohort study. Gut 2015, 65, 1359-1368. [CrossRef]

89. Caturano, A.; Acierno, C.; Nevola, R.; Pafundi, P.C.; Galiero, R.; Rinaldi, L.; Salvatore, T.; Adinolfi, L.E.; Sasso, F.C. Non-Alcoholic Fatty Liver Disease: From Pathogenesis to Clinical Impact. Processes 2021, 9, 135. [CrossRef]

90. Lonardo, A.; Lugari, S.; Ballestri, S.; Nascimbeni, F.; Baldelli, E.; Maurantonio, M. A round trip from nonalcoholic fatty liver disease to diabetes: Molecular targets to the rescue? Acta Diabetol. 2018, 56, 385-396. [CrossRef] [PubMed]

91. Bril, F.; Cusi, K. Management of Nonalcoholic Fatty Liver Disease in Patients with Type 2 Diabetes: A Call to Action. Diabetes Care 2017, 40, 419-430. [CrossRef] [PubMed]

92. Valenti, L.; Bugianesi, E.; Pajvani, U.; Targher, G. Nonalcoholic fatty liver disease: Cause or consequence of type 2 diabetes? Liver Int. 2016, 36, 1563-1579. [CrossRef] [PubMed]

93. Cusi, K.; Sanyal, A.J.; Zhang, S.; Hartman, M.L.; Bue-Valleskey, J.M.; Hoogwerf, B.J.; Haupt, A. Non-alcoholic fatty liver disease (NAFLD) prevalence and its metabolic associations in patients with type 1 diabetes and type 2 diabetes. Diabetes Obes. Metab. 2017, 19, 1630-1634. [CrossRef] [PubMed]

94. Cho, H.J.; Hwang, S.; Park, J.I.; Yang, M.J.; Hwang, J.C.; Yoo, B.M.; Lee, K.M.; Shin, S.J.; Lee, K.J.; Kim, J.H.; et al. Improvement of Nonalcoholic Fatty Liver Disease Reduces the Risk of Type 2 Diabetes Mellitus. Gut Liver 2019, 13, 440-449. [CrossRef]

95. Mantovani, A.; Petracca, G.; Beatrice, G.; Tilg, H.; Byrne, C.D.; Targher, G. Non-alcoholic fatty liver disease and risk of incident diabetes mellitus: An updated meta-analysis of 501,022 adult individuals. Gut 2020, 70, 962-969. [CrossRef]

96. Masarone, M.; Rosato, V.; Aglitti, A.; Bucci, T.; Caruso, R.; Salvatore, T.; Sasso, F.C.; Tripodi, M.F.; Persico, M. Liver biopsy in type 2 diabetes mellitus: Steatohepatitis represents the sole feature of liver damage. PLoS ONE 2017, 12, e0178473. [CrossRef] [PubMed]

97. Adinolfi, L.E.; Petta, S.; Fracanzani, A.L.; Nevola, R.; Coppola, C.; Narciso, V.; Rinaldi, L.; Calvaruso, V.; Pafundi, P.C.; Lombardi, R.; et al. Reduced incidence of type 2 diabetes in patients with chronic hepatitis $C$ virus infection cleared by direct-acting antiviral therapy: A prospective study. Diabetes Obes. Metab. 2020, 22, 2408-2416. [CrossRef] [PubMed]

98. Adinolfi, L.E.; Petta, S.; Fracanzani, A.L.; Coppola, C.; Narciso, V.; Nevola, R.; Rinaldi, L.; Calvaruso, V.; Staiano, L.; Di Marco, V.; et al. Impact of hepatitis $\mathrm{C}$ virus clearance by direct-acting antiviral treatment on the incidence of major cardiovascular events: $\mathrm{A}$ prospective multicentre study. Atherosclerosis 2020, 296, 40-47. [CrossRef] 
99. Sasso, F.C.; Pafundi, P.C.; Caturano, A.; Galiero, R.; Vetrano, E.; Nevola, R.; Petta, S.; Fracanzani, A.L.; Coppola, C.; Di Marco, V.; et al. Impact of direct acting antivirals (DAAs) on cardiovascular events in HCV cohort with pre-diabetes. Nutr. Metab. Cardiovasc. Dis. 2021, 31, 2345-2353. [CrossRef] [PubMed]

100. Aithal, G.P.; Thomas, J.; Kaye, P.V.; Lawson, A.; Ryder, S.D.; Spendlove, I.; Austin, A.S.; Freeman, J.G.; Morgan, L.; Webber, J. Randomized, Placebo-Controlled Trial of Pioglitazone in Nondiabetic Subjects with Nonalcoholic Steatohepatitis. Gastroenterology 2008, 135, 1176-1184. [CrossRef] [PubMed]

101. Gastaldelli, A.; Harrison, S.; Belfort-Aguiar, R.; Hardies, J.; Balas, B.; Schenker, S.; Cusi, K. Pioglitazone in the treatment of NASH: The role of adiponectin. Aliment. Pharmacol. Ther. 2010, 32, 769-775. [CrossRef] [PubMed]

102. Boettcher, E.; Csako, G.; Pucino, F.; Wesley, R.; Loomba, R. Meta-analysis: Pioglitazone improves liver histology and fibrosis in patients with non-alcoholic steatohepatitis. Aliment. Pharmacol. Ther. 2011, 35, 66-75. [CrossRef] [PubMed]

103. Cusi, K.; Orsak, B.; Bril, F.; Lomonaco, R.; Hecht, J.; Ortiz-Lopez, C.; Tio, F.; Hardies, J.; Darland, C.; Musi, N.; et al. Long-Term Pioglitazone Treatment for Patients with Nonalcoholic Steatohepatitis and Prediabetes or Type 2 Diabetes Mellitus. Ann. Intern. Med. 2016, 165, 305-315. [CrossRef]

104. Lian, J.; Fu, J. Efficacy of Various Hypoglycemic Agents in the Treatment of Patients with Nonalcoholic Liver Disease with or without Diabetes: A Network Meta-Analysis. Front. Endocrinol. 2021, 12, 649018. [CrossRef] [PubMed]

105. Shibuya, T.; Fushimi, N.; Kawai, M.; Yoshida, Y.; Hachiya, H.; Ito, S.; Kawai, H.; Ohashi, N.; Mori, A. Luseogliflozin improves liver fat deposition compared to metformin in type 2 diabetes patients with non-alcoholic fatty liver disease: A prospective randomized controlled pilot study. Diabetes Obes. Metab. 2017, 20, 438-442. [CrossRef] [PubMed]

106. Aso, Y.; Kato, K.; Sakurai, S.; Kishi, H.; Shimizu, M.; Jojima, T.; Iijima, T.; Maejima, Y.; Shimomura, K.; Usui, I. Impact of dapagliflozin, an SGLT2 inhibitor, on serum levels of soluble dipeptidyl peptidase-4 in patients with type 2 diabetes and non-alcoholic fatty liver disease. Int. J. Clin. Pract. 2019, 73, e13335. [CrossRef]

107. Lai, L.-L.; Vethakkan, S.R.; Mustapha, N.R.N.; Mahadeva, S.; Chan, W.-K. Empagliflozin for the Treatment of Nonalcoholic Steatohepatitis in Patients with Type 2 Diabetes Mellitus. Dig. Dis. Sci. 2019, 65, 623-631. [CrossRef]

108. Kuchay, M.S.; Krishan, S.; Mishra, S.K.; Farooqui, K.J.; Singh, M.K.; Wasir, J.S.; Bansal, B.; Kaur, P.; Jevalikar, G.; Gill, H.K.; et al Effect of Empagliflozin on Liver Fat in Patients with Type 2 Diabetes and Nonalcoholic Fatty Liver Disease: A Randomized Controlled Trial (E-LIFT Trial). Diabetes Care 2018, 41, 1801-1808. [CrossRef]

109. Shimizu, M.; Suzuki, K.; Kato, K.; Jojima, T.; Iijima, T.; Murohisa, T.; Iijima, M.; Takekawa, H.; Usui, I.; Hiraishi, H.; et al Evaluation of the effects of dapagliflozin, a sodium-glucose co-transporter-2 inhibitor, on hepatic steatosis and fibrosis using transient elastography in patients with type 2 diabetes and non-alcoholic fatty liver disease. Diabetes Obes. Metab. 2018, 21, 285-292. [CrossRef]

110. Cusi, K.; Sattar, N.; García-Pérez, L.-E.; Pavo, I.; Yu, M.; Robertson, K.E.; Karanikas, C.A.; Haupt, A. Dulaglutide decreases plasma aminotransferases in people with Type 2 diabetes in a pattern consistent with liver fat reduction: A post hoc analysis of the AWARD programme. Diabet. Med. 2018, 35, 1434-1439. [CrossRef]

111. Mantovani, A.; Petracca, G.; Beatrice, G.; Csermely, A.; Lonardo, A.; Targher, G. Glucagon-Like Peptide-1 Receptor Agonists for Treatment of Nonalcoholic Fatty Liver Disease and Nonalcoholic Steatohepatitis: An Updated Meta-Analysis of Randomized Controlled Trials. Metabolites 2021, 11, 73. [CrossRef]

112. Newsome, P.N.; Buchholtz, K.; Cusi, K.; Linder, M.; Okanoue, T.; Ratziu, V.; Sanyal, A.J.; Sejling, A.-S.; Harrison, S.A. A PlaceboControlled Trial of Subcutaneous Semaglutide in Nonalcoholic Steatohepatitis. N. Engl. J. Med. 2021, 384, 1113-1124. [CrossRef] [PubMed]

113. Song, T.; Jia, Y.; Li, Z.; Wang, F.; Ren, L.; Chen, S. Effects of Liraglutide on Nonalcoholic Fatty Liver Disease in Patients with Type 2 Diabetes Mellitus: A Systematic Review and Meta-Analysis. Diabetes Ther. 2021, 12, 1735-1749. [CrossRef] [PubMed]

114. Eguchi, Y.; Kitajima, Y.; Hyogo, H.; Takahashi, H.; Kojima, M.; Ono, M.; Araki, N.; Tanaka, K.; Yamaguchi, M.; Matsuda, Y.; et al. Pilot study of liraglutide effects in non-alcoholic steatohepatitis and non-alcoholic fatty liver disease with glucose intolerance in Japanese patients (LEAN-J). Hepatol. Res. 2014, 45, 269-278. [CrossRef] [PubMed]

115. Rizvi, A.A.; Patti, A.M.; Giglio, R.V.; Nikolic, D.; Amato, A.; Al-Busaidi, N.; Al-Rasadi, K.; Soresi, M.; Banach, M.; Montalto, G.; et al. Liraglutide improves carotid intima-media thickness in patients with type 2 diabetes and non-alcoholic fatty liver disease: An 8-month prospective pilot study. Expert Opin. Biol. Ther. 2015, 15, 1391-1397. [CrossRef]

116. Armstrong, M.; Gaunt, P.; Aithal, G.; Barton, D.; Hull, D.; Parker, R.; Hazlehurst, J.M.; Guo, K.; Abouda, G.; Aldersley, M.A.; et al. Liraglutide safety and efficacy in patients with non-alcoholic steatohepatitis (LEAN): A multicentre, double-blind, randomised, placebo-controlled phase 2 study. Lancet 2016, 387, 679-690. [CrossRef]

117. Armstrong, M.J.; Hull, D.; Guo, K.; Barton, D.; Hazlehurst, J.M.; Gathercole, L.; Nasiri, M.; Yu, J.; Gough, S.C.; Newsome, P.; et al. Glucagon-like peptide 1 decreases lipotoxicity in non-alcoholic steatohepatitis. J. Hepatol. 2015, 64, 399-408. [CrossRef]

118. Feng, W.; Gao, C.; Bi, Y.; Wu, M.; Li, P.; Shen, S.; Chen, W.; Yin, T.; Zhu, D. Randomized trial comparing the effects of gliclazide, liraglutide, and metformin on diabetes with non-alcoholic fatty liver disease. J. Diabetes 2017, 9, 800-809. [CrossRef]

119. Seko, Y.; Sumida, Y.; Tanaka, S.; Mori, K.; Taketani, H.; Ishiba, H.; Hara, T.; Okajima, A.; Umemura, A.; Nishikawa, T.; et al. Effect of 12-week dulaglutide therapy in Japanese patients with biopsy-proven non-alcoholic fatty liver disease and type 2 diabetes mellitus. Hepatol. Res. 2016, 47, 1206-1211. [CrossRef] 
120. Yan, J.; Yao, B.; Kuang, H.; Yang, X.; Huang, Q.; Hong, T.; Li, Y.; Dou, J.; Yang, W.; Qin, G.; et al. Liraglutide, Sitagliptin, and Insulin Glargine Added to Metformin: The Effect on Body Weight and Intrahepatic Lipid in Patients with Type 2 Diabetes Mellitus and Nonalcoholic Fatty Liver Disease. Hepatology 2019, 69, 2414-2426. [CrossRef]

121. Kuchay, M.S.; Krishan, S.; Mishra, S.K.; Choudhary, N.S.; Singh, M.K.; Wasir, J.S.; Kaur, P.; Gill, H.K.; Bano, T.; Farooqui, K.J.; et al. Effect of dulaglutide on liver fat in patients with type 2 diabetes and NAFLD: Randomised controlled trial (D-LIFT trial). Diabetologia 2020, 63, 2434-2445. [CrossRef]

122. Lee, K.W.; Devaraj, N.K.; Ching, S.M.; Veettil, S.K.; Hoo, F.K.; Deuraseh, I.; Soo, M.J. Effect of SGLT-2 Inhibitors on Non-alcoholic Fatty Liver Disease among Patients with Type 2 Diabetes Mellitus: Systematic Review with Meta-analysis and Trial Sequential Analysis of Randomized Clinical Trials. Oman Med. J. 2021, 36, e273. [CrossRef]

123. Hartman, M.L.; Sanyal, A.J.; Loomba, R.; Wilson, J.M.; Nikooienejad, A.; Bray, R.; Karanikas, C.A.; Duffin, K.L.; Robins, D.A.; Haupt, A. Effects of Novel Dual GIP and GLP-1 Receptor Agonist Tirzepatide on Biomarkers of Nonalcoholic Steatohepatitis in Patients with Type 2 Diabetes. Diabetes Care 2020, 43, 1352-1355. [CrossRef] [PubMed]

124. Tokushige, K.; Ikejima, K.; Ono, M.; Eguchi, Y.; Kamada, Y.; Itoh, Y.; Akuta, N.; Yoneda, M.; Iwasa, M.; Yoneda, M.; et al. Evidence-based clinical practice guidelines for nonalcoholic fatty liver disease/nonalcoholic steatohepatitis 2020. J. Gastroenterol. 2021, 56, 951-963. [CrossRef] [PubMed]

125. Ghosal, S.; Datta, D.; Sinha, B. A meta-analysis of the effects of glucagon-like-peptide 1 receptor agonist (GLP1-RA) in nonalcoholic fatty liver disease (NAFLD) with type 2 diabetes (T2D). Sci. Rep. 2021, 11, 22063. [CrossRef] [PubMed]

126. Ng, C.H.; Lin, S.Y.; Chin, Y.H.; Lee, M.H.; Syn, N.; Goh, X.L.; Koh, J.H.; Quek, J.; Tan, D.J.H.; Mok, S.F.; et al. Antidiabetic Medications for Type 2 Diabetics with Nonalcoholic Fatty Liver Disease: Evidence from a Network Meta-Analysis of Randomized Controlled Trials. Endocr. Pract. 2021; in press. [CrossRef]

127. Paik, J.M.; Golabi, P.; Younossi, Y.; Mishra, A.; Younossi, Z.M. Changes in the Global Burden of Chronic Liver Diseases from 2012 to 2017: The Growing Impact of NAFLD. Hepatology 2020, 72, 1605-1616. [CrossRef]

128. Francque, S.M.; van der Graaff, D.; Kwanten, W. Non-alcoholic fatty liver disease and cardiovascular risk: Pathophysiological mechanisms and implications. J. Hepatol. 2016, 65, 425-443. [CrossRef] [PubMed]

129. Kapuria, D.; Takyar, V.K.; Etzion, O.; Surana, P.; O’Keefe, J.H.; Koh, C. Association of Hepatic Steatosis with Subclinical Atherosclerosis: Systematic Review and Meta-Analysis. Hepatol. Commun. 2018, 2, 877-887. [CrossRef]

130. Zhou, Y.; Zhou, X.; Wu, S.; Fan, D.; Van Poucke, S.; Chen, Y.; Fu, S.; Zheng, M. Nonalcoholic fatty liver disease contributes to subclinical atherosclerosis: A systematic review and meta-analysis. Hepatol. Commun. 2018, 2, 376-392. [CrossRef]

131. Mellinger, J.L.; Pencina, K.M.; Massaro, J.M.; Hoffmann, U.; Seshadri, S.; Fox, C.S.; O’Donnell, C.J.; Speliotes, E.K. Hepatic steatosis and cardiovascular disease outcomes: An analysis of the Framingham Heart Study. J. Hepatol. 2015, 63, 470-476. [CrossRef]

132. Chalasani, N.; Younossi, Z.; LaVine, J.E.; Charlton, M.; Cusi, K.; Rinella, M.; Harrison, S.A.; Brunt, E.M.; Sanyal, A.J. The diagnosis and management of nonalcoholic fatty liver disease: Practice guidance from the American Association for the Study of Liver Diseases. Hepatology 2018, 67, 328-357. [CrossRef] [PubMed]

133. Meyersohn, N.M.; Mayrhofer, T.; Corey, K.E.; Bittner, D.O.; Staziaki, P.V.; Szilveszter, B.; Hallett, T.; Lu, M.T.; Puchner, S.B.; Simon, T.G.; et al. Association of Hepatic Steatosis with Major Adverse Cardiovascular Events, Independent of Coronary Artery Disease. Clin. Gastroenterol. Hepatol. 2020, 19, 1480-1488.e14. [CrossRef] [PubMed]

134. Simon, T.G.; Roelstraete, B.; Hagström, H.; Sundström, J.; Ludvigsson, J.F. Non-alcoholic fatty liver disease and incident major adverse cardiovascular events: Results from a nationwide histology cohort. Gut 2021, 163, 118-132. [CrossRef] [PubMed]

135. Shao, C.; Ye, J.; Li, F.; Lin, Y.; Wu, T.; Wang, W.; Feng, S.; Zhong, B. Early Predictors of Cardiovascular Disease Risk in Nonalcoholic Fatty Liver Disease: Non-obese Versus Obese Patients. Dig. Dis. Sci. 2019, 65, 1850-1860. [CrossRef]

136. Yoshitaka, H.; Hamaguchi, M.; Kojima, T.; Fukuda, T.; Ohbora, A.; Fukui, M. Nonoverweight nonalcoholic fatty liver disease and incident cardiovascular disease: A post hoc analysis of a cohort study. Medicine 2017, 96, e6712. [CrossRef]

137. Mann, J.P.; Carter, P.; Armstrong, M.J.; Abdelaziz, H.K.; Uppal, H.; Patel, B.; Chandran, S.; More, R.; Newsome, P.; Potluri, R. Hospital admission with non-alcoholic fatty liver disease is associated with increased all-cause mortality independent of cardiovascular risk factors. PLoS ONE 2020, 15, e0241357. [CrossRef] [PubMed]

138. Wu, S.; Wu, F.; Ding, Y.; Hou, J.; Bi, J.; Zhang, Z. Association of non-alcoholic fatty liver disease with major adverse cardiovascular events: A systematic review and meta-analysis. Sci. Rep. 2016, 6, 33386. [CrossRef]

139. Stepanova, M.; Younossi, Z.M. Independent Association between Nonalcoholic Fatty Liver Disease and Cardiovascular Disease in the US Population. Clin. Gastroenterol. Hepatol. 2012, 10, 646-650. [CrossRef]

140. Unalp-Arida, A.; Ruhl, C.E. Noninvasive fatty liver markers predict liver disease mortality in the U.S. population. Hepatology 2015, 63, 1170-1183. [CrossRef]

141. Alexander, M.; Loomis, A.K.; Van Der Lei, J.; Duarte-Salles, T.; Prieto-Alhambra, D.; Ansell, D.; Pasqua, A.; Lapi, F.; Rijnbeek, P.; Mosseveld, M.; et al. Non-alcoholic fatty liver disease and risk of incident acute myocardial infarction and stroke: Findings from matched cohort study of 18 million European adults. BMJ 2019, 367, 15367. [CrossRef]

142. Lee, H.; Lee, Y.-H.; Kim, S.U.; Kim, H.C. Metabolic Dysfunction-Associated Fatty Liver Disease and Incident Cardiovascular Disease Risk: A Nationwide Cohort Study. Clin. Gastroenterol. Hepatol. 2020, 19, 2138-2147.e10. [CrossRef]

143. Zhou, Y.-Y.; Zhou, X.-D.; Wu, S.-J.; Hu, X.-Q.; Tang, B.; Van Poucke, S.; Pan, X.-Y.; Wu, W.-J.; Gu, X.-M.; Fu, S.-W.; et al. Synergistic increase in cardiovascular risk in diabetes mellitus with nonalcoholic fatty liver disease: A meta-analysis. Eur. J. Gastroenterol. Hepatol. 2018, 30, 631-636. [CrossRef] [PubMed] 
144. Yan, L.; Mu, B.; Guan, Y.; Liu, X.; Zhao, N.; Pan, D.; Wang, S. Assessment of the relationship between non-alcoholic fatty liver disease and diabetic complications. J. Diabetes Investig. 2016, 7, 889-894. [CrossRef] [PubMed]

145. Agarwal, A.K.; Jain, V.; Singla, S.; Baruah, B.P.; Arya, V.; Yadav, R.; Singh, V.P. Prevalence of non-alcoholic fatty liver disease and its correlation with coronary risk factors in patients with type 2 diabetes. J. Assoc. Physicians India 2011, 59, 351-354.

146. Idilman, I.S.; Akata, D.; Hazirolan, T.; Erdogan, B.D.; Aytemir, K.; Karcaaltincaba, M. Nonalcoholic fatty liver disease is associated with significant coronary artery disease in type 2 diabetic patients: A computed tomography angiography study 2 . J. Diabetes 2015, 7, 279-286. [CrossRef]

147. Guo, K.; Zhang, L.; Lu, J.; Yu, H.; Wu, M.; Bao, Y.; Chen, H.; Jia, W. Non-alcoholic fatty liver disease is associated with late but not early atherosclerotic lesions in Chinese inpatients with type 2 diabetes. J. Diabetes Its Complicat. 2016, 31, 80-85. [CrossRef]

148. Kim, S.-K.; Choi, Y.J.; Huh, B.W.; Park, S.W.; Lee, E.J.; Cho, Y.-W.; Huh, K.B. Nonalcoholic Fatty Liver Disease Is Associated with Increased Carotid Intima-Media Thickness only in Type 2 Diabetic Subjects with Insulin Resistance. J. Clin. Endocrinol. Metab. 2014, 99, 1879-1884. [CrossRef] [PubMed]

149. Zou, Y.; Li, X.; Wang, C.; Wang, J.; Wang, F.; Ma, L.; You, W.; Li, C. Association between non-alcoholic fatty liver disease and peripheral artery disease in patients with type 2 diabetes. Intern. Med. J. 2017, 47, 1147-1153. [CrossRef]

150. Afarideh, M.; Aryan, Z.; Ghajar, A.; Ganji, M.; Ghaemi, F.; Saadat, M.; Heidari, B.; Mechanick, J.I.; Esteghamati, A. Association of non-alcoholic fatty liver disease with microvascular complications of type 2 diabetes. Prim. Care Diabetes 2019, 13, 505-514. [CrossRef]

151. Targher, G.; Bertolini, L.; Rodella, S.; Zoppini, G.; Lippi, G.; Day, C.; Muggeo, M. Non-alcoholic fatty liver disease is independently associated with an increased prevalence of chronic kidney disease and proliferative/laser-treated retinopathy in type 2 diabetic patients. Diabetologia 2007, 51, 444-450. [CrossRef]

152. Li, Y.; Zhu, S.; Li, B.; Shao, X.; Liu, X.; Liu, A.; Wu, B.; Zhang, Y.; Wang, H.; Wang, X.; et al. Association between non-alcoholic fatty liver disease and chronic kidney disease in population with prediabetes or diabetes. Int. Urol. Nephrol. 2014, 46, 1785-1791. [CrossRef] [PubMed]

153. Musso, G.; Gambino, R.; Tabibian, J.H.; Ekstedt, M.; Kechagias, S.; Hamaguchi, M.; Hultcrantz, R.; Hagström, H.; Yoon, S.K.; Charatcharoenwitthaya, P.; et al. Association of Non-alcoholic Fatty Liver Disease with Chronic Kidney Disease: A Systematic Review and Meta-analysis. PLoS Med. 2014, 11, e1001680. [CrossRef] [PubMed]

154. Lin, T.-Y.; Chen, Y.-J.; Chen, W.-L.; Peng, T.-C. The Relationship between Nonalcoholic Fatty Liver Disease and Retinopathy in NHANES III. PLoS ONE 2016, 11, e0165970. [CrossRef] [PubMed]

155. Targher, G.; Chonchol, M.; Bertolini, L.; Rodella, S.; Zenari, L.; Lippi, G.; Franchini, M.; Zoppini, G.; Muggeo, M. Increased Risk of CKD among Type 2 Diabetics with Nonalcoholic Fatty Liver Disease. J. Am. Soc. Nephrol. 2008, 19, 1564-1570. [CrossRef]

156. Koulaouzidis, G.; Charisopoulou, D.; Kukla, M.; Marlicz, W.; Rydzewska, G.; Koulaouzidis, A.; Skonieczna-Żydecka, K. Association of non-alcoholic fatty liver disease with coronary artery calcification progression: A systematic review and metaanalysis. Przeglad Gastroenterol. 2021, 16, 196-206. [CrossRef]

157. Salvatore, T.; Pafundi, P.C.; Galiero, R.; Albanese, G.; Di Martino, A.; Caturano, A.; Vetrano, E.; Rinaldi, L.; Sasso, F.C. The Diabetic Cardiomyopathy: The Contributing Pathophysiological Mechanisms. Front. Med. 2021, 8, 695792. [CrossRef]

158. Galiero, R.; Caturano, A.; Vetrano, E.; Cesaro, A.; Rinaldi, L.; Salvatore, T.; Marfella, R.; Sardu, C.; Moscarella, E.; Gragnano, F.; et al. Pathophysiological mechanisms and clinical evidence of relationship between Nonalcoholic fatty liver disease (NAFLD) and cardiovascular disease. Rev. Cardiovasc. Med. 2021, 22, 755-768. [CrossRef]

159. Targher, G.; Byrne, C.D.; Lonardo, A.; Zoppini, G.; Barbui, C. Non-alcoholic fatty liver disease and risk of incident cardiovascular disease: A meta-analysis. J. Hepatol. 2016, 65, 589-600. [CrossRef] [PubMed]

160. Lee, H.-H.; Cho, Y.; Choi, Y.J.; Huh, B.W.; Lee, B.-W.; Kang, E.S.; Park, S.W.; Cha, B.-S.; Lee, E.J.; Lee, Y.-H.; et al. Non-alcoholic steatohepatitis and progression of carotid atherosclerosis in patients with type 2 diabetes: A Korean cohort study. Cardiovasc. Diabetol. 2020, 19, 81. [CrossRef] [PubMed]

161. Greco, C.; Nascimbeni, F.; Carubbi, F.; Andreone, P.; Simoni, M.; Santi, D. Association of Nonalcoholic Fatty Liver Disease (NAFLD) with Peripheral Diabetic Polyneuropathy: A Systematic Review and Meta-Analysis. J. Clin. Med. 2021, 10, 4466. [CrossRef]

162. Santos, R.D.; Valenti, L.; Romeo, S. Does nonalcoholic fatty liver disease cause cardiovascular disease? Current knowledge and gaps. Atherosclerosis 2019, 282, 110-120. [CrossRef] [PubMed]

163. Byrne, C.D.; Targher, G. Non-alcoholic fatty liver disease is a risk factor for cardiovascular and cardiac diseases: Further evidence that a holistic approach to treatment is needed. Gut 2021, [CrossRef]

164. Lauridsen, B.K.; Stender, S.; Kristensen, T.S.; Kofoed, K.; Køber, L.; Nordestgaard, B.G.; Tybjærg-Hansen, A. Liver fat content, non-alcoholic fatty liver disease, and ischaemic heart disease: Mendelian randomization and meta-analysis of 279,013 individuals. Eur. Heart J. 2017, 39, 385-393. [CrossRef] [PubMed]

165. El-Agroudy, N.N.; Kurzbach, A.; Rodionov, R.N.; O'Sullivan, J.; Roden, M.; Birkenfeld, A.L.; Pesta, D.H. Are Lifestyle Therapies Effective for NAFLD Treatment? Trends Endocrinol. Metab. 2019, 30, 701-709. [CrossRef] [PubMed]

166. Promrat, K.; Kleiner, D.E.; Niemeier, H.M.; Jackvony, E.; Kearns, M.; Wands, J.R.; Fava, J.L.; Wing, R.R. Randomized controlled trial testing the effects of weight loss on nonalcoholic steatohepatitis. Hepatology 2010, 51, 121-129. [CrossRef]

167. Younossi, Z.M.; Koenig, A.B.; Abdelatif, D.; Fazel, Y.; Henry, L.; Wymer, M. Global epidemiology of nonalcoholic fatty liver disease-Meta-analytic assessment of prevalence, incidence, and outcomes. Hepatology 2016, 64, 73-84. [CrossRef] [PubMed] 